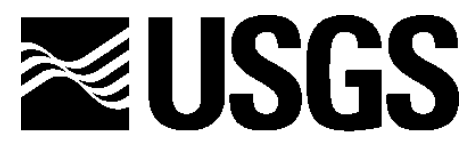

science for a changing world

Prepared in cooperation with the Bureau of Reclamation

\title{
Klamath River Water Quality Data from Link River Dam to Keno Dam, Oregon, 2008
}

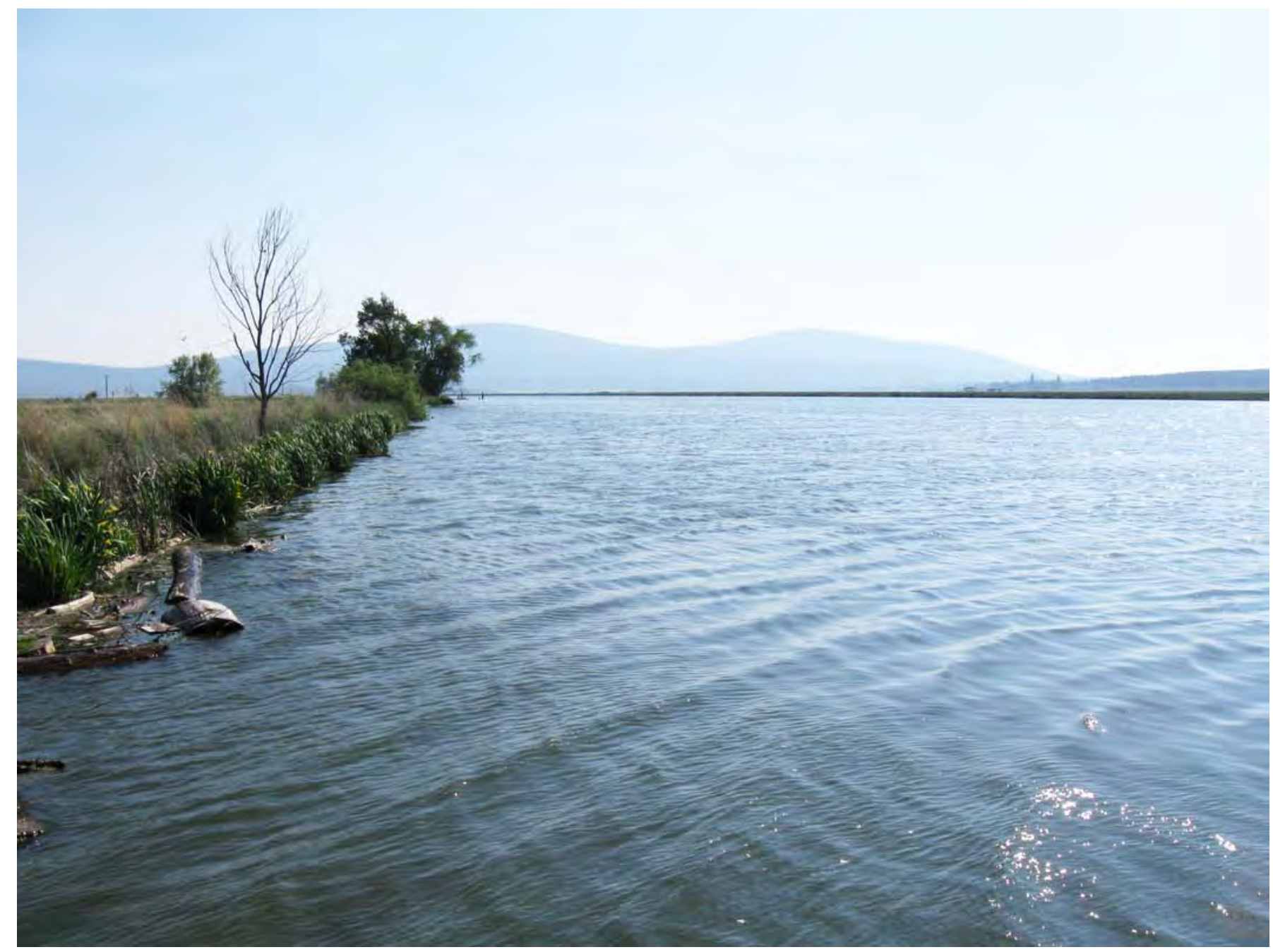

Open-File Report 2009-1105

U.S. Department of the Interior

U.S. Geological Survey 
Front cover: Klamath River at Miller Island. (Photograph by Annett Sullivan, U.S. Geological Survey, June 24, 2008) 


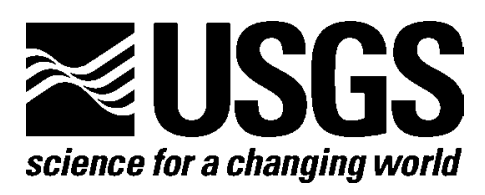

Prepared in cooperation with the Bureau of Reclamation

\section{Klamath River Water Quality Data from Link River Dam to Keno Dam, Oregon, 2008}

By Annett B. Sullivan ${ }^{1}$, Michael L. Deas², Jessica Asbill ${ }^{3}$, Julie D. Kirshtein ${ }^{4}, K^{2} n n a ~ B u t l e r{ }^{5}$, and Jennifer Vaughn²

1U.S. Geological Survey, Portland, Oregon

2Watercourse Engineering, Davis, California

3Bureau of Reclamation, Klamath Falls, Oregon

4U.S. Geological Survey, Reston, Virginia

5U.S. Geological Survey, Boulder, Colorado

Open-File Report 2009-1105

U.S. Department of the Interior

U.S. Geological Survey 


\section{U.S. Department of the Interior \\ Ken Salazar, Secretary}

\section{U.S. Geological Survey \\ Suzette M. Kimball, Acting Director}

U.S. Geological Survey, Reston, Virginia: 2009

For product and ordering information:

World Wide Web: http://www.usgs.gov/pubprod

Telephone: 1-888-ASK-USGS

For more information on the USGS—-the Federal source for science about the Earth,

its natural and living resources, natural hazards, and the environment:

World Wide Web: http://www.usgs.gov

Telephone: 1-888-ASK-USGS

Suggested citation:

Sullivan, A.B., Deas, M.L., Asbill, J., Kirshtein, J.D., Butler, K., and Vaughn, J., 2009, Klamath River water quality data from Link River Dam to Keno Dam, Oregon, 2008: U.S. Geological Survey Open File Report 2009-1105, 25 p.

Use of trade, product, or firm names is for descriptive purposes only and does not imply endorsement by the U.S. Government.

Although this report is in the public domain, permission must be secured from the individual copyright owners to reproduce any copyrighted material contained within this report. 


\section{Contents}

Abstract

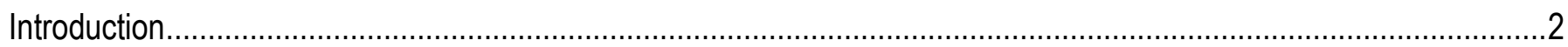

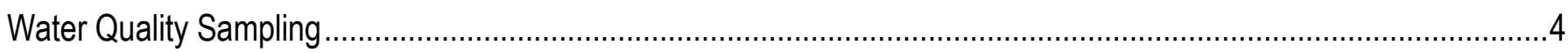

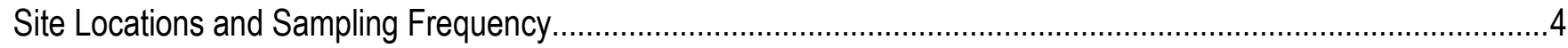

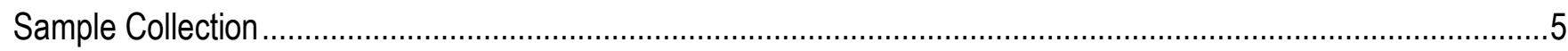

Quality Control Samples

Water Quality Analytical Methods ............................................................................................................

Nutrients, Particulate Carbon and Nitrogen, Iron, Silica, and Alkalinity.............................................................

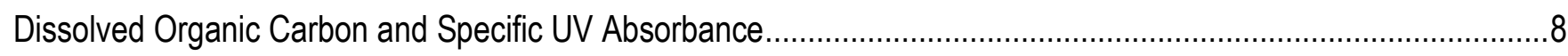

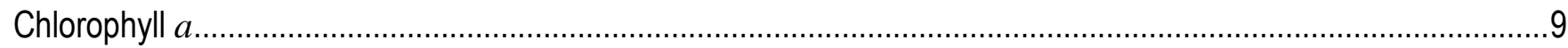

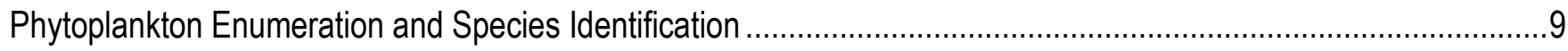

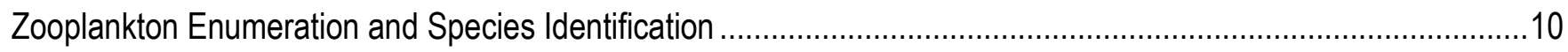

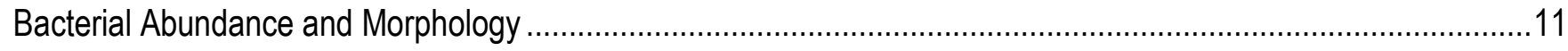

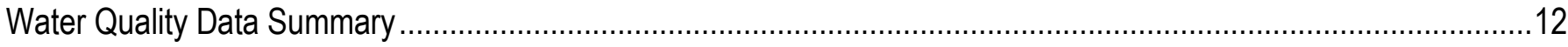

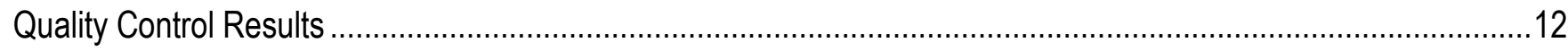

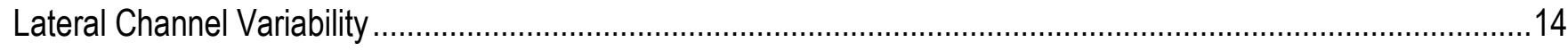

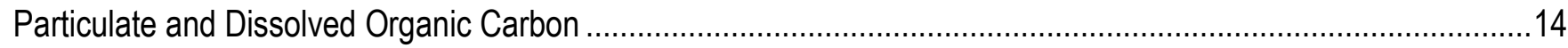

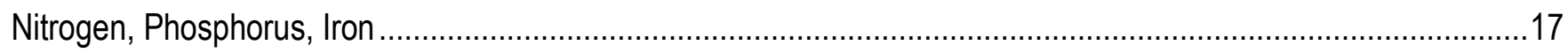

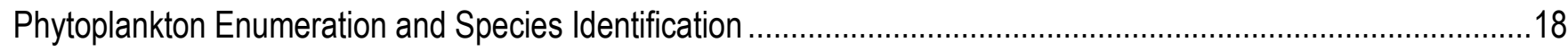

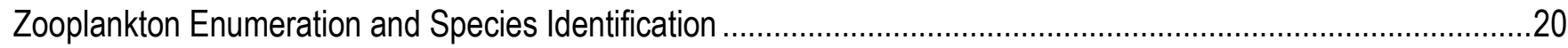

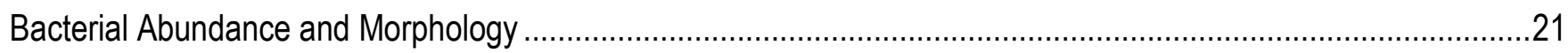

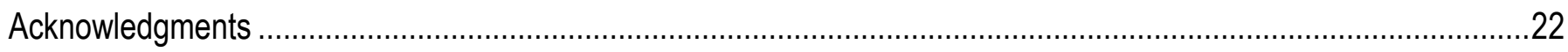

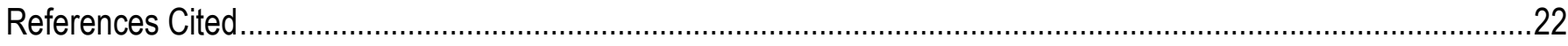

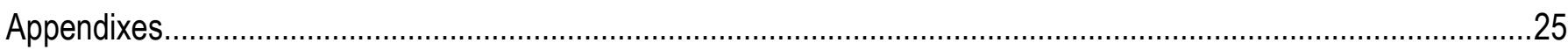

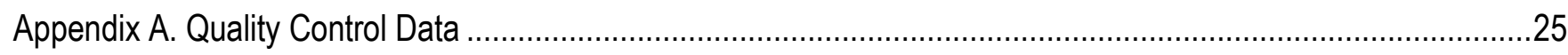

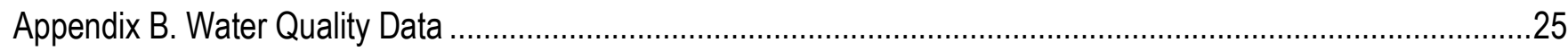

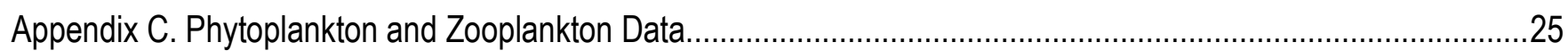

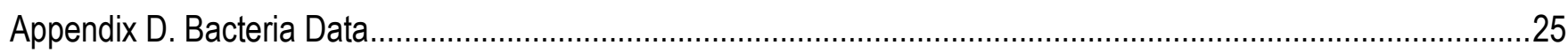




\section{Figures}

Figure 1. Map showing study area and location of water quality sampling sites in the upper Klamath River basin, Oregon.

Figure 2. Stacked charts showing seasonal variation of carbon, nitrogen, and phosphorus species, algal biovolume, zooplankton density, and bacterial biovolume at five mainstem Klamath River, Oregon, sites using median concentrations from all data collected from April through November, 2008

Figure 3. Graphs showing spatial variation of carbon, nitrogen, and phosphorus species, algal biovolume, zooplankton density, and bacterial biovolume at five mainstem Klamath River, Oregon, sites using median concentrations from all data collected from April through November, 2008.

Figure 4. Graph showing filtered iron concentrations in samples from the Link River, Oregon, 2008.

\section{Tables}

Table 1. Mainstem and tributary sampling locations, upper Klamath River basin, Oregon, 2008.

Table 2. Analyzing laboratories and method references for water quality constituents from the upper Klamath River basin, Oregon, 2008.

Table 3. Analyte reporting levels and blank results from samples collected from the upper Klamath River basin, Oregon, 2008.

Table 4. Results of analyses of duplicate quality control samples from the upper Klamath River basin, Oregon, 2008. 13

Table 5. Phytoplankton species identified in samples from the upper Klamath River basin, Oregon, 2008. 19

Table 6. Zooplankton species identified in samples from the upper Klamath River basin, Oregon, 2008. 


\section{Conversion Factors, Datums, Abbreviations, and Acronyms}

Inch/Pound to SI

\begin{tabular}{lll}
\hline \multicolumn{1}{c}{ Multiply } & \multicolumn{1}{c}{ By } & \multicolumn{1}{c}{ To obtain } \\
\hline foot (ft) & 0.3048 & meter $(\mathrm{m})$ \\
mile (mi) & 1.609 & kilometer $(\mathrm{km})$ \\
acre-foot (acre-ft) & 1,233 & cubic meter $\left(\mathrm{m}^{3}\right)$ \\
\hline SI to Inch/Pound & & \\
\hline \multicolumn{1}{c}{ Multiply } & \multicolumn{1}{c}{ By } & \multicolumn{1}{c}{ To obtain } \\
\hline nanometer $(\mathrm{nm})$ & 0.00000003937 & inch (in.) \\
micrometer $(\mu \mathrm{m})$ & 0.00003937 & inch (in.) \\
millimeter $(\mathrm{mm})$ & 0.03937 & inch (in.) \\
centimeter $(\mathrm{cm})$ & 0.3937 & inch (in.) \\
meter $(\mathrm{m})$ & 3.281 & foot (ft) \\
liter $(\mathrm{L})$ & 0.2642 & gallon (gal) \\
cubic centimeter $\left(\mathrm{cm}^{3}\right)$ & 0.06102 & cubic inch (in $\left.{ }^{3}\right)$ \\
cubic meter $\left(\mathrm{m}^{3}\right)$ & 264.2 & gallon (gal) \\
cubic meter $\left(\mathrm{m}^{3}\right)$ & 35.31 & cubic foot (ft $\left.{ }^{3}\right)$ \\
\hline
\end{tabular}

Temperature in degrees Celsius $\left({ }^{\circ} \mathrm{C}\right)$ may be converted to degrees Fahrenheit $\left({ }^{\circ} \mathrm{F}\right)$ as follows: ${ }^{\circ} \mathrm{F}=\left(1.8 x^{\circ} \mathrm{C}\right)+32$

Concentrations of chemical constituents in water are given either in milligrams per liter (mg/L), which is equivalent to parts per million, or micrograms per liter $(\mu \mathrm{g} / \mathrm{L})$, which is equivalent to parts per billion.

\section{Datums}

Vertical coordinate information is referenced to the Upper Klamath Lake Vertical Datum (UKLVD), a local datum established by the Bureau of Reclamation. For purposes of this report, UKLVD $-1.78 \mathrm{ft}=$ NGVD 29.

Horizontal coordinate information is referenced to the North American Datum of 1983 (NAD 83).

"Elevation," as used in this report, refers to distance above the vertical datum. 


\section{Abbreviations and Acronyms}

$\begin{array}{ll}\text { AFA } & \text { Aphanizomenon flos-aquae } \\ \text { AU } & \text { absorbance units } \\ \text { DOC } & \text { dissolved organic carbon } \\ \text { LT-MDL } & \text { long-term method detection limit } \\ \text { M } & \text { molarity or moles of solute per liter of solution } \\ \text { N } & \text { normality, molarity (M) multiplied by the number of protons exchanged in the reaction } \\ \text { NWQL } & \text { National Water Quality Laboratory, USGS, Denver, Colorado } \\ \text { POC } & \text { particulate organic carbon } \\ \text { Reclamation } & \text { Bureau of Reclamation } \\ \text { RL } & \text { reporting level } \\ \text { RM } & \text { river mile } \\ \text { SUVA } 254 & \text { specific UV absorbance at } 254 \mathrm{~nm} \\ \text { TSI } & \text { trophic state index } \\ \text { USGS } & \text { U.S. Geological Survey } \\ \text { UV } & \text { ultraviolet }\end{array}$




\title{
Klamath River Water Quality Data from Link River Dam to Keno Dam, Oregon, 2008
}

\author{
By Annett B. Sullivan', Michael L. Deas², Jessica Asbill³, Julie D. Kirshtein ${ }^{4}$, Kenna Butler ${ }^{5}$, and Jennifer Vaughn²
}

\begin{abstract}
This report documents sampling and analytical methods and presents field data from a second year of an ongoing study on the Klamath River from Link River Dam to Keno Dam in south central Oregon; this dataset will form the basis of a hydrodynamic and water quality model. Water quality was sampled weekly at six mainstem and two tributary sites from early April through early November, 2008. Constituents reported herein include field-measured water-column parameters (water temperature, $\mathrm{pH}$, dissolved oxygen concentration, specific conductance); total nitrogen and phosphorus; particulate carbon and nitrogen; total iron; filtered orthophosphate, nitrite, nitrite plus nitrate, ammonia, organic carbon, and iron; specific UV absorbance at 254 nanometers; chlorophyll $a$; phytoplankton and zooplankton enumeration and species identification; and bacterial abundance and morphological subgroups. Sampling program results indicated:
\end{abstract}

- Most nutrient and carbon concentrations were lowest in spring, increased starting in mid-June, remained elevated in the summer, and decreased in fall. Dissolved nitrite plus nitrate had a different seasonal cycle and was below detection or at low concentration in summer.

- Although total nitrogen and total phosphorus concentrations did not show large differences from upstream to downstream, filtered ammonia and orthophosphate concentrations increased in the downstream direction and particulate carbon and particulate nitrogen generally decreased in the downstream direction.

- Large bacterial cells made up most of the bacteria biovolume, though cocci were the most numerous bacteria type. Cocci, with diameters of 0.1 to 0.2 micrometers, were smaller than the filter pore sizes used to separate dissolved from particulate matter.

- Phytoplankton biovolumes were dominated by diatoms in spring and by the blue-green alga Aphanizomenon flos-aquae after mid-June. Another blue-green, Anabaena flos-aquae, was noted in samples from late May to late June. Phytoplankton biovolumes generally were highest at the upstream Link River and Railroad Bridge sites and decreased in the downstream direction.

- Zooplankton densities were largest in late April. Populations were dominated by rotifers and copepods in early spring, and by rotifers and cladocerans in summer, with cladocerans most common at the most upstream site.

\footnotetext{
${ }^{1}$ U.S. Geological Survey, Portland, Oregon

${ }^{2}$ Watercourse Engineering, Davis, California

${ }^{3}$ Bureau of Reclamation, Klamath Falls, Oregon

${ }^{4}$ U.S. Geological Survey, Reston, Virginia

${ }^{5}$ U.S. Geological Survey, Boulder, Colorado
} 


\section{Introduction}

The Klamath River (fig. 1), which flows from Upper Klamath Lake about $410 \mathrm{~km}$ (255 mi) through southern Oregon and northern California before emptying into the Pacific Ocean, is regulated for flow, irrigation, and hydropower generation. The first dam on the river is Link River Dam, a concrete structure owned by Bureau of Reclamation and operated by PacifiCorp to adjust levels in Upper Klamath Lake, regulate downstream flows, and divert water for irrigation or hydropower use (PacifiCorp, 2002). Link River flows for about $1 \mathrm{mi}$ downstream of Link River Dam and connects to the Klamath River. The first 2 mi of the Klamath River downstream of Link River is named Lake Ewauna, a wide and shallow reach. Keno Dam, 20 mi downstream of Link River, is a concrete reregulating facility owned by PacifiCorp and operated by PacifiCorp in coordination with the Bureau of Reclamation. Keno Dam operations are designed to provide sufficient downstream flow and a steady water surface elevation upstream of Keno Dam through the year. Normal full pool elevation at Keno is $1,245 \mathrm{~m}(4,085 \mathrm{ft})$, and total storage capacity is reported as 22.8 million $\mathrm{m}^{3}$ (18,500 acre-ft) (PacifiCorp, 2002).

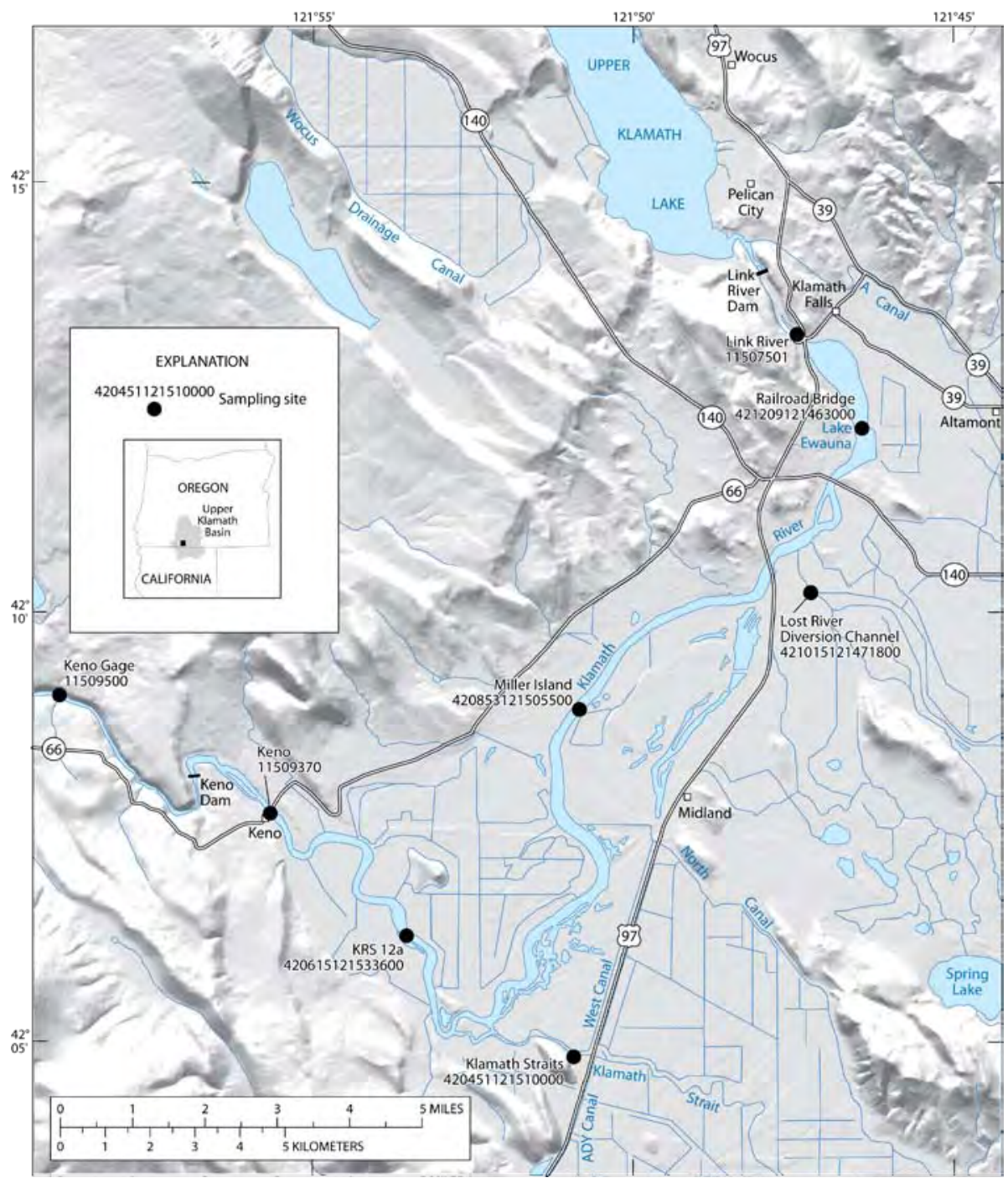

Figure 1. Study area and location of water quality sampling sites in the upper Klamath River basin, Oregon. 
The State of Oregon classifies sites in this reach as having "very poor" water quality, according to the Oregon Water Quality Index (Mrazik, 2007). In addition, this stretch of the Klamath River has been designated as "water quality limited" on Oregon's 303(d) list for ammonia and dissolved oxygen yearround, and pH and chlorophyll $a$ in summer (Oregon Department of Environmental Quality, 2007). (Section 303(d) of the Clean Water Act requires the identification of waters that do not meet water quality standards where a Total Maximum Daily Load (TMDL) needs to be developed). To address the 303(d) listing, a TMDL process is under way.

Water quality is affected by a number of factors, including upstream conditions, tributary inflows and outflows, climate, and instream processes. For instance, Upper Klamath Lake, upstream of the reach, experiences large annual blooms of the blue-green alga Aphanizomenon flos-aquae (Lindenberg and others, 2009). Inflows also include two municipal wastewater treatment plants, the Lost River Diversion Channel in spring and fall, and the Klamath Straits Drain. The Klamath Straits Drain is on Oregon's 303(d) list for ammonia and dissolved oxygen year-round, and chlorophyll $a$ (indicating excessive algal growth) in summer. To further understand the processes that contribute to water quality conditions in this reach of the Klamath River, a comprehensive suite of water quality constituents was measured at sampling intervals less than the travel time through the reach.

Sampling focused on nutrients, phytoplankton, zooplankton, and bacteria. Macronutrients such as nitrogen, phosphorus, and carbon are essential to aquatic biogeochemical cycles; the micronutrient iron has been suggested as a possible control on blue-green algal populations (Murphy and others, 1976; Kuwabara and others, 2009). Phytoplankton, especially blue-green algae, are identified as a major contributor to impaired water quality conditions in this region of the Klamath River basin. Zooplankton graze upon phytoplankton; thus, zooplankton population dynamics also can be an indicator of waterquality conditions (Ruttner-Kolisko, 1974; Pontin, 1978; Wetzel, 2001). Bacterial populations are important in nutrient cycling and make up part of water column biovolume, though they are rarely quantified in extensive sampling programs to support water quality modeling. Specific parameters sampled included:

- concentrations of total nitrogen and phosphorus

- particulate carbon and nitrogen

- total iron

- filtered orthophosphate, nitrite, nitrite plus nitrate, ammonia, organic carbon, and iron

- $\quad$ specific UV absorbance at $254 \mathrm{~nm}$

- chlorophyll $a$

- phytoplankton enumeration and species identification

- zooplankton enumeration and species identification

- bacterial abundance and morphological subgroups

During sampling, additional field-measured water quality parameters (temperature, $\mathrm{pH}$, dissolved oxygen concentration, specific conductance) were measured in the water column.

The purpose of this report is to present the methods and data from this water quality monitoring work from early April through early November 2008. Results of this project that are more experimental in nature will be reported elsewhere. These include a series of 30-day biochemical oxygen demand 
experiments, a study of 24-hour cycles of stable isotopes of oxygen, and results from four continuous acoustic Doppler uplookers deployed for 4 months. Experiments with an in situ LISST-ST instrument were completed to characterize settling rates associated with various particle sizes. Also, 12 automated, continuous monitors were deployed in the reach measuring hourly water temperature, $\mathrm{pH}$, dissolved oxygen concentration, and specific conductance; those data are available online at http://or.water.usgs.gov/proj/keno_reach/monitors.html. Together, these datasets will support interpretive analysis and model development and calibration in the reach upstream of Keno Dam by the U.S. Geological Survey (USGS), Watercourse Engineering, and Bureau of Reclamation, and provide data to others working in the Klamath Basin.

\section{Water Quality Sampling}

\section{Site Locations and Sampling Frequency}

Samples for water quality analysis were collected from six mainstem and two tributary sites (fig. 1, table 1). Sampling began the second week of April and ended the second week of November. In general, sampling was conducted weekly at the Link River, Miller Island, Keno, and Klamath Straits Drain sites, every 2 weeks at the Railroad Bridge and KRS12a sites, and monthly at the Keno gage. The Lost River Diversion channel, which conveys water both to and from the Klamath River at different times of the year, was sampled only when flow was towards the Klamath River, which occurred in spring and fall.

Table 1. Mainstem and tributary sampling locations, upper Klamath River basin, Oregon, 2008.

[Latitude and longitude format: degrees minutes seconds; Abbreviations: RM, river mile; USGS, U.S. Geological Survey]

\begin{tabular}{llllc}
\hline \multicolumn{1}{c}{ Site name } & \multicolumn{1}{c}{ USGS site No. } & Latitude & Longitude & Klamath RM \\
\hline \multicolumn{4}{c}{ Mainstem Klamath River } \\
Link River & 11507501 & 421310 & 1214725 & 253.2 \\
Railroad Bridge & 421209121463000 & 421209 & 1214630 & 251.7 \\
Miller Island & 420853121505500 & 420853 & 1215055 & 245.9 \\
KRS12a & 420615121533600 & 420615 & 1215336 & 238.3 \\
Keno & 11509370 & 420741 & 1215544 & 234.9 \\
Keno Gage & 11509500 & 420800 & 1215740 & 231.9 \\
\hline \multicolumn{4}{c}{ Tributaries } \\
Lost River Diversion Channel & 421015121471800 & 421015 & & \\
Klamath Straits Drain & 420451121510000 & 420451 & 1214718 & ${ }^{12} 249.7$ \\
\hline
\end{tabular}

${ }^{1}$ Klamath RM at confluence with tributary.

Samples for total nitrogen and phosphorus; particulate carbon and nitrogen; and filtered orthophosphate, nitrite, nitrite plus nitrate, ammonia, and organic carbon were collected at all weekly samplings. Samples for phytoplankton species identification were collected during sampling of nearsurface waters, and less frequently when samples were collected near the river bottom. Bacteria and zooplankton samples were taken every 2 weeks at mainstem sites; Klamath Straits Drain also was sampled for bacteria. Filtered iron was sampled weekly at Link River and monthly at Miller Island and Keno. Total iron was sampled monthly at Link River, Miller Island, and Keno. 


\section{Sample Collection}

During each sampling, field conditions were noted, and a vertical profile of $\mathrm{pH}$, dissolved oxygen (DO), specific conductance, and water temperature was taken with a YSI 600XLM sonde. Water samples were collected with a van Dorn sampler and processed with a churn sample splitter. At most sites, samples were collected at $0.5 \mathrm{~m}$ depth. At the mainstem sites, with the exception of Link River, a near-bottom sample also was collected for nutrients and on selected occasions for phytoplankton. Nearbottom samples were taken $1 \mathrm{~m}$ from the bottom, which was equivalent to 2.0 to $4.5 \mathrm{~m}$ from the surface depending on the site. Periodically, surface samples were collected halfway between midchannel and the left bank (facing downstream), and halfway between midchannel and the right bank, in addition to the midchannel sample. These samples were collected to examine lateral variability in water quality at four mainstem sites. All samples were kept on ice, in darkness, after collection.

Unfiltered samples collected in the field included those to be analyzed for total nitrogen and phosphorus, carbon, total iron, chlorophyll $a$, bacteria, and phytoplankton. Samples for analysis of total nitrogen and total phosphorus were preserved by adding $1 \mathrm{~mL}$ of $4.5 \mathrm{~N}$ sulfuric acid to each $125 \mathrm{~mL}$ sample bottle. Water for further processing of samples for particulate carbon and nitrogen and dissolved organic carbon was collected into 60 or $125 \mathrm{~mL}$ amber glass bottles that had been baked at $450{ }^{\circ} \mathrm{C}$ to oxidize any traces of organic carbon. Total iron was preserved with $2 \mathrm{~mL}$ of $7.7 \mathrm{~N}$ Ultrex grade nitric acid added to each $250 \mathrm{~mL}$ sample bottle. Bacteria samples were immediately preserved in 5 percent buffered formalin in $15 \mathrm{~mL}$ centrifuge tubes. Phytoplankton species samples were preserved with 1 percent Lugol's solution in $250 \mathrm{~mL}$ amber bottles.

Samples filtered in the field included those for dissolved nutrients and iron. A capsule filter (Whatman International, Kent, UK) with a $0.45 \mu \mathrm{m}$ pore size, rinsed with $500 \mathrm{~mL}$ of deionized water and $500 \mathrm{~mL}$ of sample, was used to collect these samples. Filtered near-bottom samples were pumped directly from a van Dorn sampler to the filter to minimize contact with the atmosphere in case reducing conditions were present at depth. Filtered nutrient samples were collected into brown polyethylene bottles. Filtered iron samples were preserved with $2 \mathrm{~mL}$ of $7.7 \mathrm{~N}$ Ultrex grade nitric acid added to each $250 \mathrm{~mL}$ sample bottle.

Zooplankton samples were taken by vertical tow with an $80-\mu \mathrm{m}$ mesh Wisconsin net (Wildco, Buffalo, New York) with a 130-mm mouth diameter. The net assembly was rinsed with deionized water and specimens were captured in a collector cup and transferred to a $250 \mathrm{~mL}$ sample bottle. At Link River, the current was too strong for a vertical tow, so known volumes were taken as grab samples at the surface and then passed through the zooplankton net assembly. Zooplankton samples were preserved in 23 percent isopropyl alcohol.

Immediately upon return to the Klamath Falls Bureau of Reclamation laboratory, all samples that had been collected for organic carbon analysis were filtered using baked glass fiber filters with a nominal pore size of $0.7 \mu \mathrm{m}$ and a Teflon filter apparatus, according to established USGS procedures (Wilde and others, 2004). The filtrate was collected for dissolved organic carbon (DOC) analysis, and the glass fiber filters with retained particulate matter were submitted for analysis of particulate organic carbon (POC) and particulate nitrogen. Glass fiber filters had a nominal pore size of $0.7 \mu \mathrm{m}$.

Samples were shipped on ice overnight to different laboratories performing the analyses. In early July, one cooler was delayed during shipping and arrived above the recommended temperature to the USGS dissolved organic carbon lab in Boulder, Colorado. Those samples were analyzed, but results are not reported here. 


\section{Quality Control Samples}

Quality control samples collected as a part of the sampling program included regular blanks and duplicates, with additional spikes and splits. The number of blank and duplicate samples taken for each constituent was based on guidelines from the USGS National Water-Quality Assessment program (Mueller and others, 1997), after considering Bureau of Reclamation guidelines (Bureau of Reclamation, 2005) and project needs. The number of samples used for quality control purposes for nutrients, iron, and chlorophyll $a$ ranged from 15 to 19 percent of the total number of samples. The number of quality control samples for zooplankton, phytoplankton, and bacteria samples, where blanks were unnecessary, ranged from 11 to 14 percent of the total number of samples.

Field blanks collected at various sites through the season assessed the potential for contamination from the atmosphere, equipment, sample processing, transportation, and laboratory analysis. Lab blanks assessed the potential for contamination from transportation and laboratory analysis. Both field and lab blanks were collected using USGS-certified blank water. Blank results were evaluated in comparison to reporting levels (RL) determined by the laboratory for each constituent. For the parameters analyzed at the USGS National Water Quality Laboratory (NWQL) in Denver, Colorado, the laboratory RL was equal to twice the long-term method detection level (LT-MDL), which is determined statistically on an annual basis (Childress and others, 1999).

Duplicate samples were taken to estimate variability from sampling and analysis. Most field duplicates, taken at various sites through the season, were taken as subsamples from the same grab sample (that is, using a churn sample splitter). Zooplankton duplicates, collected as sequential replicates, were the exception. The variability between duplicates was analyzed by calculating absolute differences and relative percent differences (RPD):

$$
R P D=\left|\frac{(\text { Value } 1-\text { Value } 2)}{(\text { Value } 1+\text { Value } 2) / 2}\right| \times 100
$$

RPD was calculated for duplicates with concentrations $>5 \mathrm{x}$ (more than five times) the reporting limit because percent differences for samples near the reporting limit can be high, even with small absolute differences.

Spiked samples are samples to which a known mass of the constituents of interest are added. A duplicate set of nutrient spikes were included to analyze percent recovery of total phosphate, total nitrogen, orthophosphate, ammonia and nitrate plus nitrite. The spiked samples were designed to give final concentrations $>2 x$ greater than the average historical background level, or $>5 x$ the laboratory RL, whichever was greater (Bureau of Reclamation, 2005).

Laboratory splits are replicate sample sets collected and sent to different laboratories to analyze laboratory precision. Sample splits are samples collected with different sampling techniques and sent to the same laboratory to analyze sampling precision. To examine whether chlorophyll $a$ degradation occurred in the time between shipping and analysis, twice during the season (August and September) a set of chlorophyll $a$ splits were filtered and frozen immediately upon return from the field and shipped on dry ice to the laboratory. A paired set was sent unfrozen, on regular ice, according to the usual sampling protocol. During the September test, a third set was filtered and frozen upon return from the field, and shipped on dry ice to a different laboratory (the USGS Oregon Water Science Center) to assess interlaboratory performance. 


\section{Water Quality Analytical Methods}

\section{Nutrients, Particulate Carbon and Nitrogen, Iron, Silica, and Alkalinity}

Nutrients, particulate carbon and nitrogen, and iron were analyzed at the NWQL (table 2). Total phosphorus and total nitrogen concentrations were determined by alkaline persulfate digestion (Patton and Kryskalla, 2003). Orthophosphate was determined by colorimetry by reaction with ammonium molybdate in acidic solution to form phosphomolybdic acid, then reduction with ascorbic acid (Fishman, 1993). Nitrite was analyzed by colorimetry via reaction with sulfanilamide under acidic conditions to form a diazo compound that couples with N-1-naphthylethylenediamine dihydrochloride (Fishman, 1993). Nitrite plus nitrate was determined similarly, but nitrate was first reduced to nitrite with cadmium metal. Ammonia was measured by colorimetry through reaction with salicylate and hypochlorite in the presence of ferricyanide ions (Fishman, 1993). Iron was analyzed with inductively coupled plasma atomic emission spectrometry (Fishman, 1993). All concentrations for nitrogen constituents are stated in $\mathrm{mg} / \mathrm{L}$ as $\mathrm{N}$, and all concentrations reported for phosphorus constituents are reported as $\mathrm{mg} / \mathrm{L}$ as $\mathrm{P}$.

Table 2. Analyzing laboratories and method references for water quality constituents from the upper Klamath River basin, Oregon, 2008.

[Additional details on analytical methods are described in the text. Abbreviations: NWQL, National Water Quality Laboratory; P, phosphorus; N, nitrogen; USGS, U.S. Geological Survey; SUVA, specific ultraviolet absorbance]

\begin{tabular}{lll}
\hline \multicolumn{1}{c}{ Analyte } & \multicolumn{1}{c}{ Laboratory } & \multicolumn{1}{c}{ Method reference } \\
\hline Orthophosphate, as P & USGS NWQL, Denver, Colorado & Fishman, 1993 \\
Ammonia, as N & USGS NWQL, Denver, Colorado & Fishman, 1993 \\
Nitrate and nitrite, as N & USGS NWQL, Denver, Colorado & Fishman, 1993 \\
Nitrite, as N & USGS NWQL, Denver, Colorado & Fishman, 1993 \\
Total phosphorus & USGS NWQL, Denver, Colorado & Patton and Kryskalla, 2003 \\
Total nitrogen & USGS NWQL, Denver, Colorado & Patton and Kryskalla, 2003 \\
Particulate carbon & USGS NWQL, Denver, Colorado & Zimmerman and others, 1997 \\
Particulate nitrogen & USGS NWQL, Denver, Colorado & Zimmerman and others, 1997 \\
Iron & USGS NWQL, Denver, Colorado & Fishman, 1993 \\
Dissolved organic carbon & USGS, Boulder, Colorado & Aiken, 1992 \\
SUVA & USGS, Boulder, Colorado & Weishaar and others, 2003 \\
Total bacterial abundance & USGS, Reston, Virginia & Noble and Fuhrman, 1998; Weinbauer \\
Chlorophyll $a$ & and others, 1998 \\
Phytoplankton, total density & Aquatic Analysts, Milwaukee, Oregon & American Public Health Association, \\
& ZP's Taxonomic Services, Olympia, & American Public Health Association, \\
Zooplankton, total density & American Public Health Association, \\
\hline
\end{tabular}

Particulate carbon and nitrogen concentrations were analyzed by combusting particulates retained on glass fiber filters in pure oxygen at $975^{\circ} \mathrm{C}$ (Zimmerman and others, 1997). The carbon and nitrogen combustion products were converted to $\mathrm{CO}_{2}$ and $\mathrm{N}_{2}$, and detected by thermal conductivity. In many systems particulate inorganic carbon is minimal, so the value of total particulate carbon is equivalent to particulate organic carbon (POC). To test this assumption, in previous work at the Link River and Keno 
sites, a second set of sample filters were baked at a temperature to remove organic carbon, but leave behind particulate inorganic carbon for measurement. In these analyses, particulate inorganic carbon was always below detection, so results for total particulate carbon were assumed equal to POC.

NWQL has thorough internal quality assurance protocols, including standard reference samples, blanks, replicates, spikes, and calibration standards, as documented in Friedman and Erdmann (1982), Jones (1987), Pritt and Raese (1995), and Maloney (2005). Samples analyzed at NWQL used USGScertified field supplies during sampling including filters, bottles, and preservatives. Those supplies are subject to testing, inspection, and other quality assurance procedures (U.S. Geological Survey, 2007).

\section{Dissolved Organic Carbon and Specific UV Absorbance}

DOC concentrations were measured using the platinum catalyzed persulfate wet oxidation method on an O.I. Analytical Model 700 TOC AnalyzerTM (Aiken, 1992; Schuster, 2003), with the instrument initialized at least 4 hours before analysis. Samples and standards were loaded onto an autosampler and introduced into the reaction vessel by means of a fixed-volume sample loop. The volume of the sample loop was kept small, usually $1 \mathrm{~mL}$, to maintain linear instrument response (0-50 $\mu \mathrm{g}$ of carbon). The standard, automated analytical conditions called for $0.5 \mathrm{~mL}$ of 5 percent by volume phosphoric acid added to the sample. The sample then was purged for 120 seconds with nitrogen to remove inorganic carbon, after which $0.5 \mathrm{~mL}$ of $0.42 \mathrm{M}$ sodium persulfate solution was added. The standard reaction time of 5 minutes was used for the persulfate oxidation step. The instrument was calibrated with solutions of reagent-grade potassium hydrogen phthalate in distilled water. The standard curve, consisting of a minimum of 5 standards over the range of interest, was repeated for every 10-12 water samples analyzed in duplicate. All values are the averages of duplicate analyses. Standard deviation for the DOC measurement was $\pm 0.2 \mathrm{mg} / \mathrm{L}$.

Ultraviolet-visible absorbance analyses (UV-Vis; between 200 and $800 \mathrm{~nm}$ ) were made on a Hewlett-Packard Model $8453^{\mathrm{TM}}$ photo-diode array spectrophotometer with distilled water as the blank using a 1-cm path-length quartz cell. Dissolved organic matter is a complex mixture of organic compounds, and absorbance measurements provide additional insight into its composition. A wavelength of $254 \mathrm{~nm}$ was chosen because it is the wavelength commonly associated with the aromatic moieties in a sample (Weishaar and others, 2003). Filtered samples at room temperature were analyzed using a quartz cell in the manual mode. The cell was rinsed with a small volume of sample before adding sample for analysis. The cell was then rinsed with distilled water before analyzing the next sample. Standard deviation for a UV absorbance measurement at $254 \mathrm{~nm}$ was \pm 0.002 absorbance units (AU).

Specific UV absorbance (SUVA), defined as the UV absorbance of a sample measured at a given wavelength divided by the DOC concentration, is an average molar absorbance for all the molecules that compose the DOC in a water sample. Dissolved organic carbon is made up of a complex mixture of compounds, and SUVA can help indicate the nature and origin of DOC in a given sample. For example, it has been used as a surrogate measurement of the percent aromaticity of that mixture of compounds (Weishaar and others, 2003). SUVA values at $254 \mathrm{~nm}$ (SUVA254) are reported here because natural organic matter absorbs strongly at this wavelength, thereby giving increased sensitivity, and because of the strong correlation with the aromatic carbon content of natural organic matter at this wavelength. Values are reported in units of $\mathrm{L} /(\mathrm{mg}-\mathrm{m})$ and have a standard deviation of $\pm 0.1 \mathrm{~L} /(\mathrm{mg}-\mathrm{m})$. 


\section{Chlorophyll $a$}

Samples for chlorophyll $a$ were analyzed following procedures for spectrophotometric analysis described in method $10200 \mathrm{H}$ in American Public Health Association (2005). The entire chlorophyll $a$ sample was filtered ( $47 \mathrm{~mm}$ Whatman $\mathrm{GF} / \mathrm{C} 1.2 \mu \mathrm{m}$ pore size) immediately upon arrival in the chlorophyll analytical laboratory to avoid problems associated with taking subsamples of water containing large particulate matter. The detection limit varied depending on sample volume which was dependent on algal concentration in the river. For $1,000 \mathrm{~mL}$ samples, the detection limit was $0.5 \mu \mathrm{g} / \mathrm{L}$, and for $100 \mathrm{~mL}$ samples, the detection limit was $5 \mu \mathrm{g} / \mathrm{L}$.

\section{Phytoplankton Enumeration and Species Identification}

Analysis of phytoplankton included enumeration, identification, and estimations of biovolume. Permanent microscope slides were prepared by filtering an aliquot of each sample through a $0.45 \mu \mathrm{m}$ membrane filter (McNabb, 1960; American Public Health Association, 2005). A section of filter was cut out and placed on a glass slide with immersion oil added to make the filter transparent. A cover slip was placed over the filter section, with clear nail polish applied to the periphery for permanency. The slides are archived indefinitely; water samples were placed in storage for at least 1 year.

Enumeration of phytoplankton (algal) units (defined as discrete particles - cells, colonies, or filaments) was completed by counting along a measured transect of the microscope slide with a Zeiss standard microscope $(1,000 x$; phase contrast). Only algae that were believed to be alive at the time of collection (intact chloroplast) were counted. At least 100 algal units were counted. Algae were identified using an extensive library of literature too numerous to reference herein, including journal reprints, standard reference books, and internet reference sites. Most algae were identified by cross-referencing several taxonomic sources. Algal densities were calculated from the area observed (transect length times diameter of field of view), the effective filter area, and the volume of sample filtered.

The microscope was calibrated using a standard concentration of latex spheres, 12,075 spheres/mL, provided by the U.S. Environmental Protection Agency (Cincinnati, Ohio). Duplicate preparations of the standard spheres were analyzed, with an average result of 11,700 spheres/mL. A computer program used to calculate algal densities compensated for this 3.1 percent error. The analyzing laboratory has participated in the analysis of split algae samples on several occasions, with general agreement between samples in terms of algae density and algae species composition. Also on occasion, independent algae analysts have been contracted by the laboratory for second opinions on some difficult-to-identify algae species.

Average biovolume estimates of each species were obtained from calculations of microscopic measurements of each algal unit, accurate to $0.1 \mathrm{~mm}$ with a stage micrometer. The number of cells per colony or the length of a filament was recorded during sample analysis to arrive at biovolume per unitalga. Average biovolumes and measurements were verified for each sample analyzed.

Trophic State Index (TSI) based upon phytoplankton biovolume was developed from a data set of several hundred lakes located throughout the Pacific Northwest (Sweet, 1986). The index was derived in a similar fashion as Carlson (1977) derived indices for Secchi depth, chlorophyll $a$ concentration, and total phosphorus concentration, and values agree well with Carlson's indices. The unitless biovolume index ranges from 1 for ultraoligotrophic lakes to 100 for hypereutrophic lakes. The index is defined as:

$$
\text { TSI }(\text { biovolume })=\left(\log _{2}(B+1)\right) * 5
$$

where $B$ is phytoplankton biovolume in $\mu \mathrm{m}^{3} / \mathrm{mL}$ divided by 1,000 . 


\section{Zooplankton Enumeration and Species Identification}

Analysis of zooplankton species included identification and enumeration (American Public Health Association, 2005). Samples were first split with a Folsom plankton splitter until an approximate subsample size of 400 total individual arthropods and 100 individuals of the most abundant species were reached. If the initial split did not achieve both of these criteria, then increasingly larger splits were enumerated until both criteria were met, or until the entire sample was counted. All rotifers and protozoans in the split were completely enumerated as well, unless their numbers significantly exceeded 400 individuals, in which case a separate rotifer subsplit was made and counted for rotifers and protozoans. The statistical methodology for this approach was based upon Edmondson and Winberg (1971, p. 178) and assumed that the sampling methods (both in the field and during the splitting) followed a Poisson distribution. This assumption is violated for larger species such as those of Chaoborus and Leptodora; thus, all individuals of those taxa found in a sample were enumerated. The selected values of 400 and 100 individuals provided a maximum statistical standard error of the mean of 5 and 10 percent, respectively (the formula used is: $\mathrm{s}=1 / \sqrt{ } \mathrm{N}$, where $\mathrm{N}$ is the number of individuals found belonging to the taxon in question). Although the confidence limits for only total numbers and most abundant species were set by this procedure, the standard error of the mean for each species could be determined from the original tallies, using the previous formula for the Poisson distribution. Results are reported in numbers per cubic meter, and standard errors for each value are included in Appendix C.

Standard zooplankton enumeration was done with a Wild M-3 microscope at 32x magnification. Samples were counted in an open counting chamber with six parallel channels following the procedures described in Edmondson and Winberg (1971, p. 131). Species identifications were made at higher levels of magnification under a compound microscope as needed. General taxonomic identifications followed Edmondson (1959), Pennak (1989), and Thorp and Covich (1991). Specific group references used include Berner (1994), Brooks (1957), Brandlova and others (1972), Deevey and Deevey (1971), DeMont and Hebert (1994), Dumont and Pensaert (1983), Hebert (2001), Korovchinsky (1992), Patterson (1996), Pontin (1978), Ruttner-Kolisko (1974), Stemberger (1979), and Taylor and others (2002). Identifications were to species for all adult and subadult crustaceans, excepting harpacticoid copepods and ostracods, and for most rotifers. Immature copepods through copepodite stage IV were identified as far as their developmental stage allowed. Confirmation of the identifications was made with results from previous investigations in the region of the study area.

For length-frequency analysis, crustacean lengths were taken following the protocols described in Edmondson and Winberg (1971). Specifically, cladocerans were measured from the top of the head (helmet included) to the posterior edge of the carapace excluding any tail spine or mucro, and copepods were measured from the end of the cephalothorax to the end of the caudal rami, exclusive of the setae.

An estimate of the intensity of planktivory based upon the density and relative abundance of the edible species present was made for each sample. Evaluation of the availability of the different zooplankton species as food items for particular species of fish was based upon an ongoing literature review starting with Brooks (1969) and continuing with Kerfoot (1980), Zaret (1980), and Carpenter and Kitchell (1993). This evaluation was kept up-to-date by regular reviews of recently published zooplankton predation studies in Limnology and Oceanography, and the Proceedings of the International Association of Theoretical and Applied Limnology (Verhein International Verein Limnologie), as well as the results of articles such as Eilers and others (2007). The earlier literature has been summarized in Canale and others $(1975,1976)$. 
Quality assurance included microscope calibration, replicate samples, independent analysis, and internal data verification. The basic quality control method used for enumerating zooplankton samples was the standard error value, an estimator of within-sample variability. Quality assurance and control for within-sample variability was maintained by routine re-analysis of 2 to 3 percent of all samples examined. The samples re-analyzed were selected at random, using a random number generator and the unique sequence number of each sample analyzed. Statistical analyses of past replicated counts indicated that the standard error values adequately estimate between 90 and 98 percent of all withinsample variability.

Unlike the statistical parameter standard deviation, standard error does not provide a betweensample estimator of the population variance. Field replicate samples were collected to assess betweensample variability. Between-sample replicates taken at the same time and place have significantly higher variability due to plankton patchiness and species "swarms."

\section{Bacterial Abundance and Morphology}

Processing of bacteria samples were based on protocols from Noble and Fuhrman (1998), and Weinbauer and others (1998). Samples were stained for 15 min in the dark using Sybr Green I stain (Molecular Probes, Eugene, Oregon) at 1:5,000 dilution, and were filtered under gentle vacuum $(<10$ $\mathrm{kPa}$ ) onto a $0.2 \mu \mathrm{m}$ aluminum oxide Anodisc 25 filter (Whatman International, Kent, UK) backed by a $0.45 \mu \mathrm{m}$ cellulose nitrate membrane filter (Fisher Scientific, Pittsburgh, Pennsylvania). The Anodisc filter was mounted on a glass slide with a drop of antifade solution $(\sim 50$ percent glycerol, $\sim 50$ percent phosphate buffered saline, 0.5 percent ascorbic acid) and a $25-\mathrm{mm}$-square coverslip. Total cells were enumerated under blue excitation using a Zeiss epifluorescent microscope (Axio A1). At least 250 cells from at least 5 fields were counted per filter. Autofluorescent, bacteria-sized cells also were enumerated using a bandpass filter with emission from 575 to $640 \mathrm{~nm}$. Attached cells were counted where possible.

Three groups of bacteria were enumerated based on size and morphology:

- Group 1. Large cells

- Group 2. Vibrios

- Group 3. Small cocci

Group 1 bacteria were mostly stubby rods (over 90 percent), but also included narrower or longer rods and diplococci $>0.5 \mu \mathrm{m}$. Although it is not possible to determine bacterial identification and metabolic function based on morphology, this group could include Gram-negative, respiratory bacteria (aerobes, facultative anaerobes) phenotypically related to members of the genus Pseudomonas. Many bacteria in this physiological group are free-living in soil and water, and play an important role in decomposition, biodegradation, and carbon and nitrogen cycles. Some display bioluminescence, such as photobacteria. Group 1 bacteria also could include gram-positive fermentative bacteria or enteric bacteria.

Vibrios, which make up Group 2 bacteria, are Gram-negative bacteria that have the cell shape of a curved rod or a comma. Members of the genus Vibrio are common in aquatic environments, and have structural and metabolic properties that overlap with both the enterics and the pseudomonads. In aquatic habitats they overlap with the pseudomonads in their ecology (decomposition, biodegradation, and carbon and nitrogen cycles).

Group 3 bacteria are cocci, spherical, or oval bacteria. Their size in this system was mostly $0.1-0.2$ $\mu \mathrm{m}$, rarely with cells larger than or equal to $0.5 \mu \mathrm{m}$ ( $<1$ percent). 
Bacteria play a key role in recycling organic and inorganic matter, and constitute part of the pool of organic matter in aquatic ecosystems. Populations and dimensions of the three bacterial morphologies were used to estimate bacterial biovolume, and can be used to estimate bacterial biomass. Separation into morphological groups is important with these calculations, because changes in the populations of larger cells may have a disproportional contribution to biovolume.

\section{Water Quality Data Summary}

Water quality data summarized here are provided in appendix tables and graphs (Excel files) that can be accessed through links at the end of the text. A brief data summary is presented below to highlight quality control results, seasonal trends, concentration ranges, differences between concentrations at the top and bottom of the water column, major species, and notable trends between sites.

\section{Quality Control Results}

Program-level quality assurance for blanks assumes that when field blank concentrations are less than the RL, regular samples are free of contamination. It is further assumed that systematic blank results higher than the RL are notable, whereas rare random blanks higher than the RL are of less concern. For analytes with reporting levels, concentrations in 163 of 165 blanks ( $>98$ percent) analyzed throughout the sampling season were below the RL (table 3): the two blanks above the RL were dissolved organic carbon blanks of 1.1 and $1.2 \mathrm{mg} / \mathrm{L}$, above the $0.7 \mathrm{mg} / \mathrm{L} \mathrm{RL}$. An RL was not designated for UV absorbance, but blank values were near zero, and much lower than all measured field values. Blank results showed no evidence of systematic contamination.

Table 3. Analyte reporting levels and blank results from samples collected from the upper Klamath River basin, Oregon, 2008.

[Abbreviations: RL, reporting level; mg/L, milligrams per liter; P, phosphorus; N, nitrogen; >, greater than; <, less than; NA, no blanks were above RL; *, RL not determined, median and range of all blanks given; v, detection and reporting limit varies depending on sample size; UV, ultraviolet]

\begin{tabular}{lccccc}
\hline \multicolumn{1}{c}{ Analyte } & Units & RL & $\begin{array}{c}\text { Number of } \\
\text { blanks }\end{array}$ & $\begin{array}{c}\text { Number of } \\
\text { blanks }>\text { RL }\end{array}$ & Value of blanks $>$ RL \\
\hline Orthophosphate, as $\mathrm{P}$ & $\mathrm{mg} / \mathrm{L}$ & 0.006 & 18 & 0 & $\mathrm{NA}$ \\
Ammonia, as N & $\mathrm{mg} / \mathrm{L}$ & 0.02 & 18 & 0 & $\mathrm{NA}$ \\
Nitrate and nitrite, as $\mathrm{N}$ & $\mathrm{mg} / \mathrm{L}$ & 0.04 & 18 & 0 & $\mathrm{NA}$ \\
Nitrite, as N & $\mathrm{mg} / \mathrm{L}$ & 0.002 & 18 & 0 & $\mathrm{NA}$ \\
Total phosphorus & $\mathrm{mg} / \mathrm{L}$ & 0.02 & 18 & 0 & $\mathrm{NA}$ \\
Total nitrogen & $\mathrm{mg} / \mathrm{L}$ & 0.06 & 18 & 0 & $\mathrm{NA}$ \\
Particulate carbon & $\mathrm{mg} / \mathrm{L}$ & 0.14 & 9 & 0 & $\mathrm{NA}$ \\
Particulate nitrogen & $\mathrm{mg} / \mathrm{L}$ & 0.04 & 9 & 0 & $\mathrm{NA}$ \\
Iron & $\mu \mathrm{g} / \mathrm{L}$ & 8 & 6 & 0 & $\mathrm{NA}$ \\
Dissolved organic carbon & $\mathrm{mg} / \mathrm{L}$ & 0.7 & 14 & 2 & $1.1,1.2$ \\
UV absorbance & $1 / \mathrm{m}$ & $*$ & 14 & $*$ & median: 0.002 \\
Chlorophyll $a$ & $\mu \mathrm{g} / \mathrm{L}$ & $\mathrm{v}$ & 5 & 0 & range: $<0.001-0.004$ \\
\hline
\end{tabular}


Analyses of the majority of duplicate filtered samples showed low variability (table 4). Medians of duplicates $(\geq 5 \mathrm{x}$ RL) for filtered orthophosphate, ammonia, nitrite, DOC, and UV absorbance were 4 percent RPD or less. Concentrations of nitrate plus nitrite were low enough that none of the duplicates were greater than 5x RL. Overall, there was higher variability for duplicates of unfiltered samples. There is greater uncertainty with these data due to the inherent difficulties of sampling particulate matter. For instance, the macroscopic size and tendency of Aphanizomenon flos aquae (AFA) to form clumps likely would contribute to variability in phytoplankton counts, particulate carbon, particulate nitrogen, total nitrogen, and total phosphorus. Largest median RPDs were determined for analyses that involved microscopic examination and enumeration of particulate material, like phytoplankton, zooplankton, and bacteria.

Table 4. Results of analyses of duplicate quality control samples from the upper Klamath River basin, Oregon, 2008.

[Abbreviations: mg/L, milligrams per liter; Dup., number of duplicate samples; RPD, relative percent difference; $\geq$, greater than or equal to; RL, reporting level; pctl, percentile; NA, no duplicate results were $\geq 5 \mathrm{x}$ (five times) RL; *, RL was not determined, so RPD was calculated for all duplicates; P, phosphorus; N, nitrogen; UV, ultraviolet; \#, number]

\begin{tabular}{|c|c|c|c|c|c|c|c|}
\hline \multirow{3}{*}{ Analyte } & \multirow{3}{*}{$\begin{array}{l}\text { Field } \\
\text { filtered }\end{array}$} & \multirow{3}{*}{ Dup. } & \multirow{3}{*}{ Units } & \multicolumn{4}{|c|}{ Difference between duplicates } \\
\hline & & & & \multicolumn{2}{|c|}{ Absolute difference } & \multicolumn{2}{|c|}{$\begin{array}{c}\mathrm{RPD} \text { (percent) } \\
\text { (for duplicate } \geq 5 \times \mathrm{RL} \text { ) }\end{array}$} \\
\hline & & & & Median & $10^{\text {th }} \mathrm{pctl} \mid 90^{\text {th }} \mathrm{pctl}$ & Median & $10^{\text {th }} \mathrm{pctl} \mid 90^{\text {th }} \mathrm{pct}$ \\
\hline Orthophosphate, as $\mathrm{P}$ & yes & 16 & $\mathrm{mg} / \mathrm{L}$ & 0.001 & $0.000 \mid 0.002$ & 1.1 & $0.0 \mid 2.0$ \\
\hline Ammonia, as $\mathrm{N}$ & yes & 16 & $\mathrm{mg} / \mathrm{L}$ & 0.003 & $0.000 \mid 0.023$ & 3.5 & $0.9 \mid 6.9$ \\
\hline Nitrate and nitrite, as $\mathrm{N}$ & yes & 16 & $\mathrm{mg} / \mathrm{L}$ & 0.000 & $0.000 \mid 0.003$ & NA & NA \\
\hline Nitrite, as $\mathrm{N}$ & yes & 16 & $\mathrm{mg} / \mathrm{L}$ & 0.000 & $0.000 \mid 0.001$ & 0.0 & $0.0 \mid 0.0$ \\
\hline Total phosphorus & & 16 & $\mathrm{mg} / \mathrm{L}$ & 0.02 & $0.00 \mid 0.04$ & 7.5 & $0.0 \mid 15.3$ \\
\hline Total nitrogen & & 16 & $\mathrm{mg} / \mathrm{L}$ & 0.07 & $0.02 \mid 0.28$ & 3.3 & $0.6 \mid 14.2$ \\
\hline Particulate carbon & & 16 & $\mathrm{mg} / \mathrm{L}$ & 0.31 & $0.05 \mid 1.92$ & 6.7 & $3.0 \mid 33.1$ \\
\hline Particulate nitrogen & & 16 & $\mathrm{mg} / \mathrm{L}$ & 0.04 & $0.02 \mid 0.40$ & 7.7 & $2.3 \mid 42.2$ \\
\hline Iron & yes & 3 & $\mu \mathrm{g} / \mathrm{L}$ & 9 & $3 \mid 12$ & 11.5 & $5.7 \mid 11.6$ \\
\hline Dissolved organic carbon & yes & 15 & $\mathrm{mg} / \mathrm{L}$ & 0.1 & $0.0 \mid 1.0$ & 1.0 & $0.0 \mid 9.9$ \\
\hline UV absorbance & yes & 15 & $1 / \mathrm{m}$ & 0.002 & $0.000 \mid 0.004$ & 0.6 & $0.0 \mid 2.6$ \\
\hline Bacterial abundance & & 7 & $\begin{array}{l}10^{6} \\
\text { cells } / \mathrm{mL}\end{array}$ & 14.7 & $4.2 \mid 16.6$ & 46.8 & $11.1 \mid 134$ \\
\hline Chlorophyll $a$ & & 11 & $\mu \mathrm{g} / \mathrm{L}$ & 2.60 & $0.10 \mid 16.0$ & 5.8 & $2.3 \mid 13.3$ \\
\hline Phytoplankton, density & & 13 & $\# / \mathrm{mL}$ & 603 & $152 \mid 5,835$ & 18.7 & $2.5 \mid 43.7$ \\
\hline Zooplankton, density & & 6 & $\# / \mathrm{m}^{3}$ & 17,406 & $1,207 \mid 35,764$ & 24.6 & $15.6 \mid 54.3$ \\
\hline
\end{tabular}


Recovery of nutrients in the two spiked samples averaged 97 percent, with a range of 88 to 109 percent. Spike acceptance criteria were designated to be between 80 and 120 percent (Bureau of Reclamation, 2005). More details on spike results are available in Appendix A.

Split chlorophyll a samples showed no bias between samples that were filtered at the analytical laboratory compared to those that were filtered in the field lab and shipped frozen to the analytical laboratory. Comparison of a paired set of field lab-filtered, frozen samples shipped to the two different laboratories showed the Boise-analyzed samples to be slightly lower and the Portland-analyzed samples to be slightly higher, by an average of about $20 \mu \mathrm{g} / \mathrm{L}$, with a median RPD of 12.6 percent. Further details on split and other quality control results are presented in Appendix A.

\section{Lateral Channel Variability}

To examine whether notable lateral variability occurred, median RPDs were calculated for the right-bank/midchannel and left-bank/midchannel pairs and compared to RPDs for duplicate samples collected as part of the quality control program. As expected, RPDs for samples collected across the channel were larger than for quality control duplicates. However, at times and for certain constituents, some of the differences were more notable than others. The maximum and highest median RPDs for these samples were for particulate carbon, particulate nitrogen, chlorophyll a, phytoplankton density, and zooplankton density. The sample set with the greatest difference across the channel was taken at Railroad Bridge on July 22. Left-bank and right-bank data are included in Appendices B, C, and D.

\section{Particulate and Dissolved Organic Carbon}

Concentrations of particulate organic carbon (POC) ranged from 0.45 to $19.7 \mathrm{mg} / \mathrm{L}$ at mainstem sites; concentrations were generally low in April, increased in June, peaked in July or early August at most sites, gradually decreasing later in the season (fig. 2; Appendix B). Concentrations at the top and bottom of the water column were similar in spring (April-May) and fall (October-November), with more variation in summer; when different, POC concentrations were generally higher near the surface, but depending on the site or date, concentrations were sometimes higher at the bottom of the water column.

Dissolved organic carbon (DOC) concentrations at mainstem sites ranged from 4.9 to $13.5 \mathrm{mg} / \mathrm{L}$. Like POC, concentrations of DOC were lowest in spring, increased into summer, and decreased in fall (fig. 2); however, peak concentrations of DOC occurred later in the season, in September. DOC concentrations at the top and bottom of the water column were similar. SUVA 254 , a measure of the aromaticity of DOC, ranged from 2.0 to $3.2 \mathrm{~L} /(\mathrm{mg}-\mathrm{m})$, with lowest values in September.

Together, POC and DOC make up total organic carbon. Averaged over the sampling period, particulate carbon constituted 36 percent of total organic carbon at Link River, 30 percent at Railroad Bridge, 21 percent at Miller Island, 20 percent at KRS12a, and 18 percent at Keno, decreasing in the downstream direction (fig. 3). Depending on the date or site, POC could make up from 5 to 69 percent of total organic carbon.

POC concentrations in the Klamath Straits Drain and Lost River Diversion Channel ranged from 0.58 to $10.8 \mathrm{mg} / \mathrm{L}$ through the season, with highest concentrations generally in April. The Klamath Straits Drain had higher DOC concentrations than the mainstem, ranging from 13.1 to $32.6 \mathrm{mg} / \mathrm{L}$, with highest concentrations in April and a gradual decrease over the season. DOC concentrations in the Lost River Diversion Channel were more similar to concentrations in the mainstem Klamath River. SUVA 254 ranged from 2.3 to $3.3 \mathrm{~L} /(\mathrm{mg}-\mathrm{m})$ in those two tributaries. 

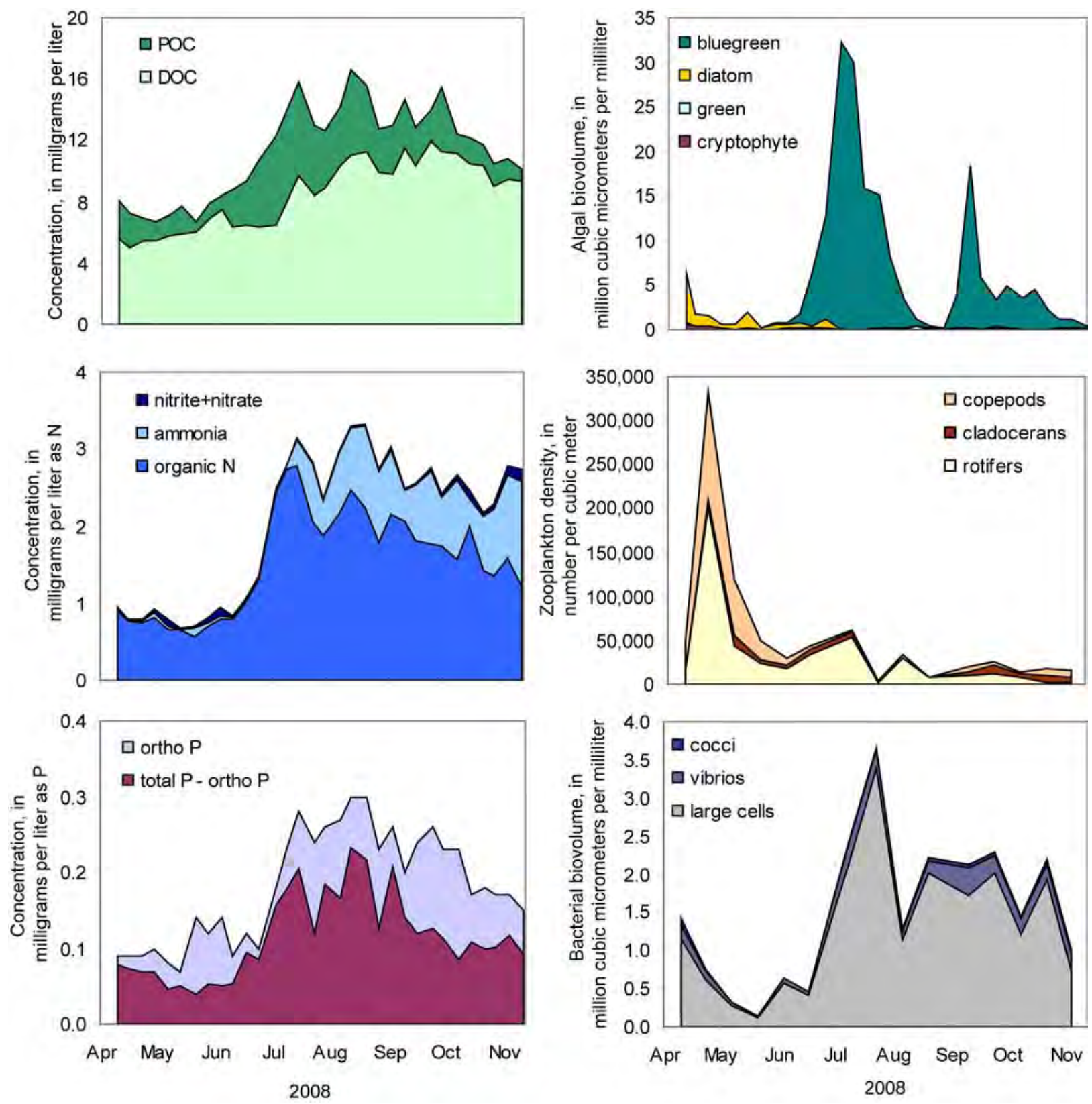

Figure 2. Stacked charts showing seasonal variation of carbon, nitrogen, and phosphorus species, algal biovolume, zooplankton density, and bacterial biovolume at five mainstem Klamath River, Oregon, sites using median concentrations from all data collected from April through November, 2008. Most samples were collected weekly, except zooplankton and bacteria, collected every two weeks. [POC, particulate organic carbon; DOC, dissolved organic carbon; $\mathrm{P}$, phosphorus; $\mathrm{N}$, nitrogen] 

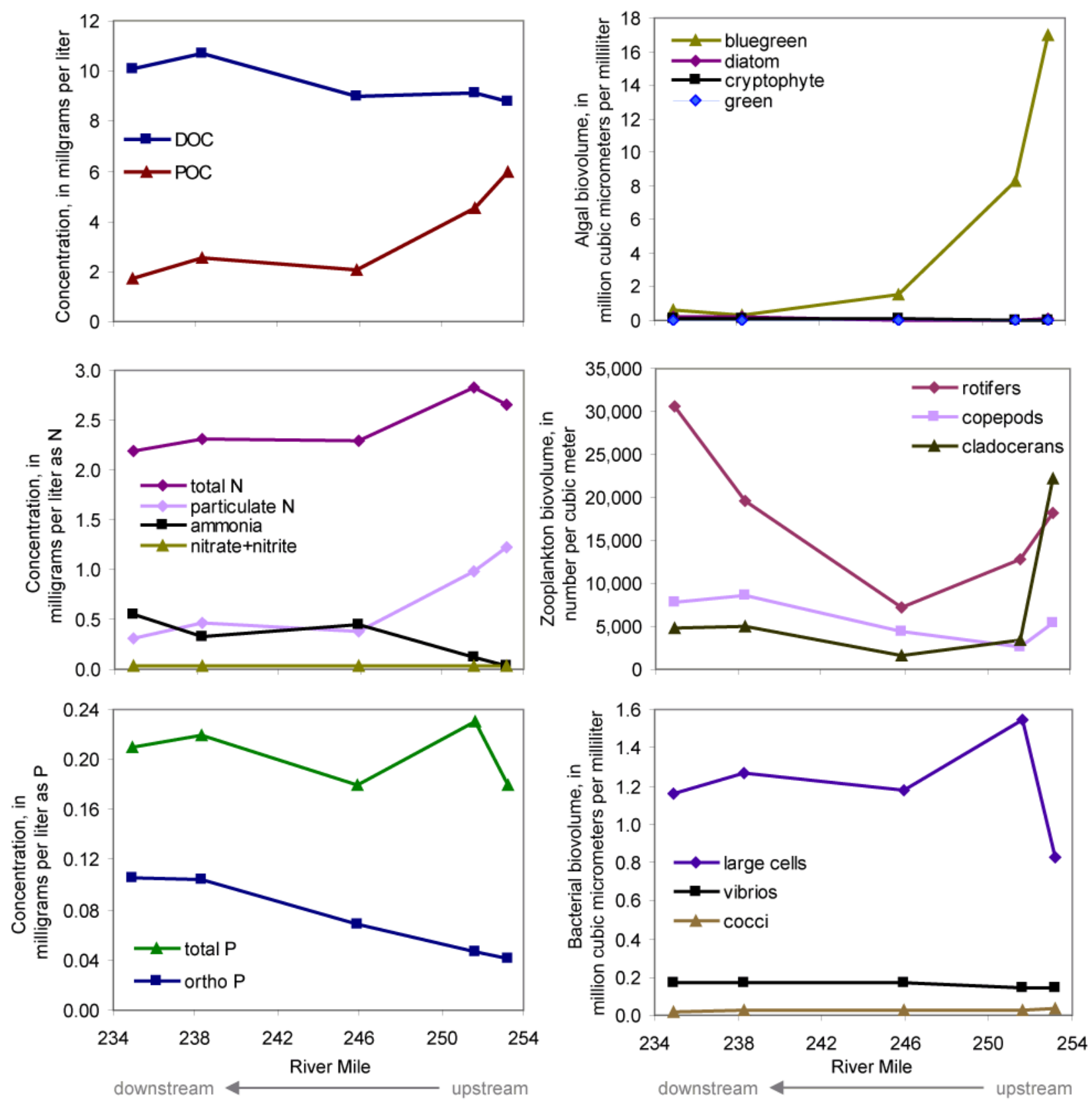

Figure 3. Spatial variation of carbon, nitrogen, and phosphorus species, algal biovolume, zooplankton density, and bacterial biovolume at five mainstem Klamath River, Oregon, sites using median concentrations from all data collected from April through November, 2008. Flow is from right to left. [DOC, dissolved organic carbon; $\mathrm{POC}$, particulate organic carbon; $\mathrm{P}$, phosphorus; $\mathrm{N}$, nitrogen] 


\section{Nitrogen, Phosphorus, and Iron}

At mainstem sites, the total nitrogen concentration was lowest in April and May, increased in late June and early July, and gradually decreased late in the sampling season (fig. 2; Appendix B); concentrations at mainstem sites ranged from 0.62 to $5.43 \mathrm{mg} / \mathrm{L}$. Concentrations at the top and bottom of the water column were similar at most samplings. Considering data from the whole sampling season, median total nitrogen was only slightly higher at the two most upstream sites, Link River and Railroad Bridge, compared to sites further downstream (fig. 3). Particulate nitrogen, a component of "organic N" in figure 2, had seasonal patterns similar to total nitrogen, with mainstem concentrations from 0.06 to $4.05 \mathrm{mg} / \mathrm{L}$. In general, the percent of total nitrogen that was particulate was greater at upstream sites (fig. 3).

Ammonia concentrations just downstream from Upper Klamath Lake, at Link River, were below $0.070 \mathrm{mg} / \mathrm{L}$ and fairly constant until early October, when concentrations increased to as much as 1.12 $\mathrm{mg} / \mathrm{L}$ at the last sampling in mid-November. The seasonal pattern at that site was different from that at mainstem sites further downstream, which experienced increases in ammonia concentrations by midJuly, with maximums in summer. At some of the farther downstream sites, on some dates in summer, ammonia also varied substantially (over 100 percent difference calculated as RPD) between the top and bottom of the water column; when such differences occurred, higher concentrations usually were in bottom samples. Averaged over the entire sampling season, ammonia concentrations at mainstem sites increased in the downstream direction: $0.108 \mathrm{mg} / \mathrm{L}$ at Link River, $0.260 \mathrm{mg} / \mathrm{L}$ at Railroad Bridge, 0.495 $\mathrm{mg} / \mathrm{L}$ at Miller Island, $0.560 \mathrm{mg} / \mathrm{L}$ at KRS12a, and $0.580 \mathrm{mg} / \mathrm{L}$ at Keno; median values (fig. 3) show a similar trend.

Concentrations of nitrate plus nitrite at mainstem sites were, with a few exceptions, below the reporting level $(0.040 \mathrm{mg} / \mathrm{L})$ from July 8 to August 27 , and some sites' concentrations were below the reporting level as early as April 9 (Link River), or as late as September 30 (Keno). Concentrations at the top and bottom of the water column were similar. Filtered nitrite, which has a lower reporting level $(0.002 \mathrm{mg} / \mathrm{L})$ than nitrate plus nitrite, remained above the reporting level at most mainstem sites, though at low concentrations. At mainstem sites, nitrite concentrations ranged up to $0.024 \mathrm{mg} / \mathrm{L}$.

Total phosphorus concentrations at mainstem sites ranged between 0.05 to $0.42 \mathrm{mg} / \mathrm{L}$, and filtered orthophosphate concentrations ranged between 0.010 and $0.211 \mathrm{mg} / \mathrm{L}$. Both total phosphorus and filtered orthophosphate concentrations at mainstem sites increased into summer and decreased into fall (fig. 2). During most weeks, orthophosphate increased in the downstream direction (fig. 3).

Filtered iron concentrations at Link River increased from a minimum of $46 \mu \mathrm{g} / \mathrm{L}$ in mid-April to a measured maximum of $128 \mu \mathrm{g} / \mathrm{L}$ in early July (fig. 4). Concentrations decreased through the next month, before leveling off. Other downstream sites were sampled less frequently, but concentrations were in the same range as those at Link River, and there was little difference between samples taken at the top of the water column and bottom. Total iron concentrations, sampled less frequently, ranged from 140 to $374 \mu \mathrm{g} / \mathrm{L}$. 


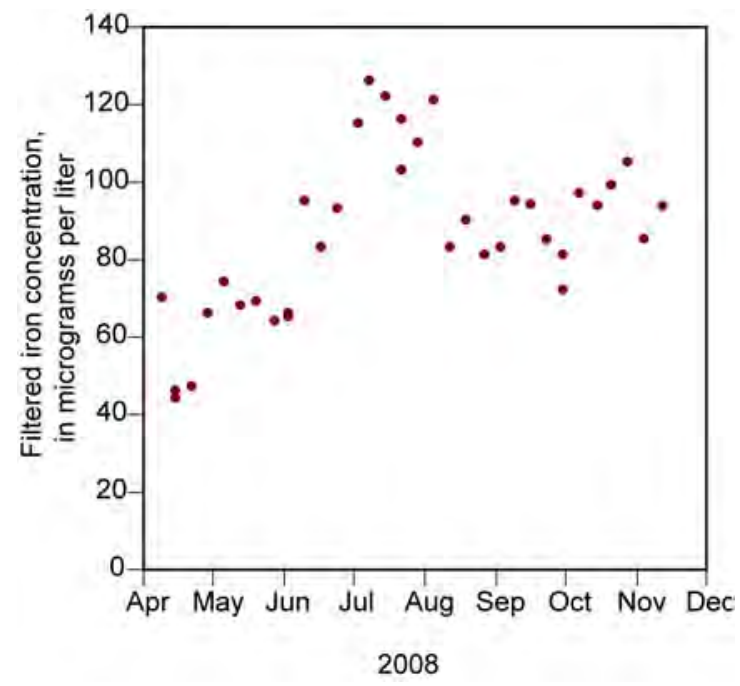

Figure 4. Filtered iron concentrations in samples from the Link River, Oregon, 2008.
In the Klamath Straits Drain and Lost River Diversion Channel, tributaries to the mainstem Klamath River, concentrations of total nitrogen ranged from $0.99 \mathrm{mg} / \mathrm{L}$ to 4.52 $\mathrm{mg} / \mathrm{L}$ and particulate nitrogen from $0.10 \mathrm{mg} / \mathrm{L}$ to $1.44 \mathrm{mg} / \mathrm{L}$; seasonal cycles were not strongly apparent, though the highest concentrations in the Klamath Straits Drain were measured early in the season, in April. Ammonia concentrations ranged from below detection to $1.06 \mathrm{mg} / \mathrm{L}$, with the higher concentrations in summer and fall. Nitrite plus nitrate concentrations ranged from below detection to $0.668 \mathrm{mg} / \mathrm{L}$. Nitrite concentrations ranged from below detection to $0.112 \mathrm{mg} / \mathrm{L}$. Total phosphorus concentrations ranged from 0.17 to $0.62 \mathrm{mg} / \mathrm{L}$, and orthophosphate from 0.051 to $0.390 \mathrm{mg} / \mathrm{L}$.

\section{Phytoplankton Enumeration and Species Identification}

A total of 141 algae species were identified in 2008 samples (table 5). Most of these algae (98.8 percent) belonged to one of four algal groups: blue-green, cryptophytes, diatoms, and green (Appendix C). The cryptophyte Rhodomonas minuta was the most frequently identified species, followed by Cryptomonas erosa, another cryptophyte, and AFA, a blue-green alga. AFA was the species with the highest average density, 61 percent, when present.

For mainstem sites, phytoplankton biovolumes were less than 10 million $\mu \mathrm{m}^{3} / \mathrm{mL}$ from April through June and then increased in late June and early July (fig. 2; Appendix C). The study's maximum biovolume of nearly 60 million $\mu \mathrm{m}^{3} / \mathrm{mL}$ occurred at Railroad Bridge in mid-July. Although biovolumes remained above 15 million $\mu \mathrm{m}^{3} / \mathrm{mL}$ at the upstream Link River and Railroad Bridge sites, biovolumes decreased to less than 2 million $\mu \mathrm{m}^{3} / \mathrm{mL}$ at the four most downstream sites (Miller Island, KRS12a, Keno, Keno Gage) in mid- to late August. Concentrations were higher at those again in September before continuing to decrease through November. Samples collected at the top and bottom of the water column sometimes had large differences in concentration (sometimes greater than 100 percent difference calculated as RPD); concentrations nearer the surface were generally higher than those near the bottom. For the Klamath Straits Drain and Lost River Diversion Channel tributaries, where the number of samples collected was smaller than for mainstem sites, biovolumes ranged from 256,000 to $5,870,000 \mu \mathrm{m}^{3} / \mathrm{mL}$.

The algal group composition varied seasonally throughout the study. In spring, diatoms represented 56 percent of the total algal biovolume at mainstem sites, followed by blue-green algae ( 24 percent) and cryptophytes (14 percent). In summer, blue-green algae represented 76 percent of the total algae biovolume, followed by green algae (10 percent) and diatoms ( 7 percent). In fall, blue-green algae remained the most abundant algal group, representing 80 percent of the total algal biovolume, followed by diatoms ( 15 percent) and cryptophytes ( 4 percent). 
Table 5. Phytoplankton species identified in samples from the upper Klamath River basin, Oregon, 2008

\begin{tabular}{|c|c|c|c|}
\hline $\begin{array}{l}\text { BLUE-GREEN } \\
\text { Anabaena flos-aquae }\end{array}$ & $\begin{array}{l}\text { DIATOM (continued) } \\
\text { Cymbella tumida }\end{array}$ & $\begin{array}{l}\text { DIATOM (continued) } \\
\text { Navicula pupula }\end{array}$ & $\begin{array}{l}\text { GREEN } \\
\text { Actinastrum hantzschii }\end{array}$ \\
\hline Anabaenopsis sp. & Diatoma tenue & Navicula pygmaea & Ankistrodesmus falcatus \\
\hline Aphanizomenon flos-aquae & Diatoma tenue elongatum & Navicula rhynchocephala & Botryococcus braunii \\
\hline Oscillatoria sp. & Diatoma vulgare & Navicula sp. & Characium sp. \\
\hline CHRYSOPHYTE & Epithemia sorex & Navicula tripunctata & Chlamydomonas sp. \\
\hline Chromulina sp. & Epithemia turgida & Nitzschia acicularis & Cladophora sp. \\
\hline Chrysococcus rufescens & Eunotia pectinalis & Nitzschia amphibia & Closteriopsis longissima \\
\hline Kephyrion sp. & $\begin{array}{l}\text { Fragilaria capucina } \\
\text { mesolepta }\end{array}$ & Nitzschia capitellata & Crucigenia quadrata \\
\hline Mallomonas sp. & Fragilaria construens & Nitzschia communis & $\begin{array}{l}\text { Dictyosphaerium } \\
\text { ehrenbergianum }\end{array}$ \\
\hline CRYPTOPHYTE & Fragilaria construens venter & Nitzschia dissipata & Elakatothrix gelatinosa \\
\hline Cryptomonas erosa & Fragilaria crotonensis & Nitzschia fonticola & Eudorina elegans \\
\hline Cryptomonas ovata & Fragilaria leptostauron & Nitzschia frustulum & Gloeocystis ampla \\
\hline Rhodomonas minuta & Fragilaria pinnata & Nitzschia linearis & Golenkinia radiata \\
\hline Achnanthes clevei & Fragilaria sp. & Nitzschia microcephala & Mougeotia sp. \\
\hline Achnanthes exigua & Fragilaria vaucheriae & Nitzschia palea & Oocystis parva \\
\hline Achnanthes hauckiana & Fragilaria virescens & Nitzschia paleacea & Oocystis pusilla \\
\hline DIATOM & Gomphoneis herculeana & Nitzschia recta & Pediastrum boryanum \\
\hline Achnanthes lanceolata & Gomphonema acuminatum & Nitzschia sp. & Pediastrum duplex \\
\hline Achnanthes linearis & Gomphonema angustatum & Nitzschia tryblionella & Scenedesmus abundans \\
\hline Achnanthes minutissima & Gomphonema olivaceum & Nitzschia volcanica & Scenedesmus acuminatus \\
\hline Amphora ovalis & Gomphonema subclavatum & Pinnularia borealis & Scenedesmus bijuga \\
\hline Amphora perpusilla & Gomphonema tenellum & Pinnularia sp. & Scenedesmus quadricauda \\
\hline Asterionella formosa & Gomphonema truncatum & Rhoicosphenia curvata & Scenedesmus sp. \\
\hline Caloneis sp. & Gomphonema ventricosum & Stauroneis sp. & Schroderia sp. \\
\hline Caloneis ventricosa & Melosira ambigua & $\begin{array}{l}\text { Stephanodiscus astraea } \\
\text { minutula }\end{array}$ & Selenastrum minutum \\
\hline Caloneis ventricosa minuta & Melosira granulata & Stephanodiscus hantzschii & Sphaerocystis schroeteri \\
\hline Cocconeis klamathensis & Melosira varians & Stephanodiscus niagarae & Tetraedron minimum \\
\hline Cocconeis placentula & Navicula anglica & Surirella linearis & Tetraedron regulare \\
\hline Cyclotella meneghiniana & Navicula capitata & Synedra cyclopum & $\begin{array}{l}\text { Tetrastrum } \\
\text { staurogeniaforme }\end{array}$ \\
\hline Cyclotella ocellata & Navicula cascadensis & Synedra parasitica & Ulothrix sp. \\
\hline Cyclotella pseudostelligera & Navicula cryptocephala & Synedra radians & DINOFLAGELLATE \\
\hline Cyclotella stelligera & $\begin{array}{l}\text { Navicula cryptocephala } \\
\text { veneta }\end{array}$ & Synedra ulna & Glenodinium sp. \\
\hline Cymatopleura solea & Navicula graciloides & Synedra ulna contracta & UNKNOWN \\
\hline Cymbella affinis & $\begin{array}{l}\text { Navicula menisculus } \\
\text { upsaliensis }\end{array}$ & EUGLENOID & Unidentified flagellate \\
\hline Cymbella mexicana & Navicula minima & Euglena sp. & \\
\hline Cymbella microcephala & Navicula minuscula & Trachelomonas hispida & \\
\hline Cymbella minuta & Navicula mutica & Trachelomonas volvocina & \\
\hline Cymbella sp. & Navicula pseudoscutiformis & & \\
\hline
\end{tabular}


At Link River and Railroad Bridge, blue-green algae made up almost 100 percent of all algae species from early July through late October. With increasing distance downstream, blue-green algae were less dominant after early July. At KRS12a, Keno, and Keno Gage, blue-greens were still common, but periods with notable green, diatom, and cryptophyte populations occurred. Although AFA composed most of the blue-green algae group, Anabaena flos-aquae was identified in samples from late May through late June.

The two sites in tributaries to the Klamath River had different overall compositions of algal groups. The most abundant group in Lost River Diversion Channel and Klamath Straits Drain was diatoms (79 and 50 percent, respectively). At Lost River, cryptophytes represented 11 percent of the total algal biovolume followed by green algae (7 percent), and at Klamath Straits Drain, blue-green algae was the second most abundant algal group ( 30 percent) followed by green algae (11 percent).

The trophic state index (TSI) for mainstem sites ranged from 27.7 to 79.3 . Of the phytoplankton samples collected in this year, 4 samples had TSI considered "oligotrophic," 49 as "mesotrophic," 99 as "eutrophic," and 47 as "hypereutrophic," according to the classification system in Atlas of Oregon Lakes (Johnson and others, 1985).

\section{Zooplankton Enumeration and Species Identification}

A total of 68 species were collected in 2008 (table 6). Most of the zooplankton collected during the study belonged to one of three groups: cladocerans, copepods, and rotifers; these three groups represented 99.5 percent of the total density of zooplankton in 2008 (Appendix C). The most frequently identified cladocerans were Daphnia pulicaria and Chydorus sphaericus, the most frequently identified copepods were cyclopoid copepodites (intermediate to late stage cyclopoid copepods of undetermined species) and copepod nauplii (early stage copepods of undetermined species), and the most frequently identified rotifers were Keratella hiemalis and Euchlanis dilatata.

During the initial sampling in early April, zooplankton densities for all species combined were highest at the Link River and Keno Reservoir sites, with densities slightly more than $200,000 / \mathrm{m}^{3}$. Railroad Bridge, Miller Island, and KRS12a had lower total densities: slightly less than $50,000 / \mathrm{m}^{3}$ at each site. Zooplankton densities reached a maximum in late April at all sites (fig. 2; Appendix C). During this period, the highest density occurred at Link River, with more than $550,000 / \mathrm{m}^{3}$. After peaking in April, densities declined until July, when zooplankton densities increased again at all sites. The highest increase occurred at KRS12a, with a density slightly less than $180,000 / \mathrm{m}^{3}$. The densities at the other four sites did not exceed $100,000 / \mathrm{m}^{3}$. This increase was quickly followed by a decrease to combined densities of zooplankton of less than $40,000 / \mathrm{m}^{3}$ for all sites at the end of July. In early August, densities increased again at Link River, Railroad Bridge and Keno Reservoir. Miller Island and KRS12a zooplankton densities did not increase until late August and early September. Following these small density increases, zooplankton densities remained relatively constant from September through the end of the sampling program in early November. During this period, densities ranged from about 10,000 to $70,000 / \mathrm{m}^{3}$.

The zooplankton group composition fluctuated seasonally (fig. 2). In spring (April-June), rotifers were the most abundant group, accounting for 48 percent of the total density, followed by copepods, with 41 percent, and cladocerans, with 10 percent of total density. In summer (July-September), rotifers were again the most abundant group of zooplankton ( 70 percent), followed by cladocerans (19 percent) 
and copepods (10 percent). In fall (October-November), cladocerans were the most abundant group (47 percent), followed by copepods (32 percent) and rotifers (21 percent).

Comparisons by median density by site indicated that at Link River, cladocerans were generally most abundant, followed by rotifers and copepods (fig. 3). At all other mainstem sites, rotifers were on average the most abundant group of zooplankton, followed by copepods and cladocerans.

Table 6. Zooplankton species identified in samples from the upper Klamath River basin, Oregon, 2008

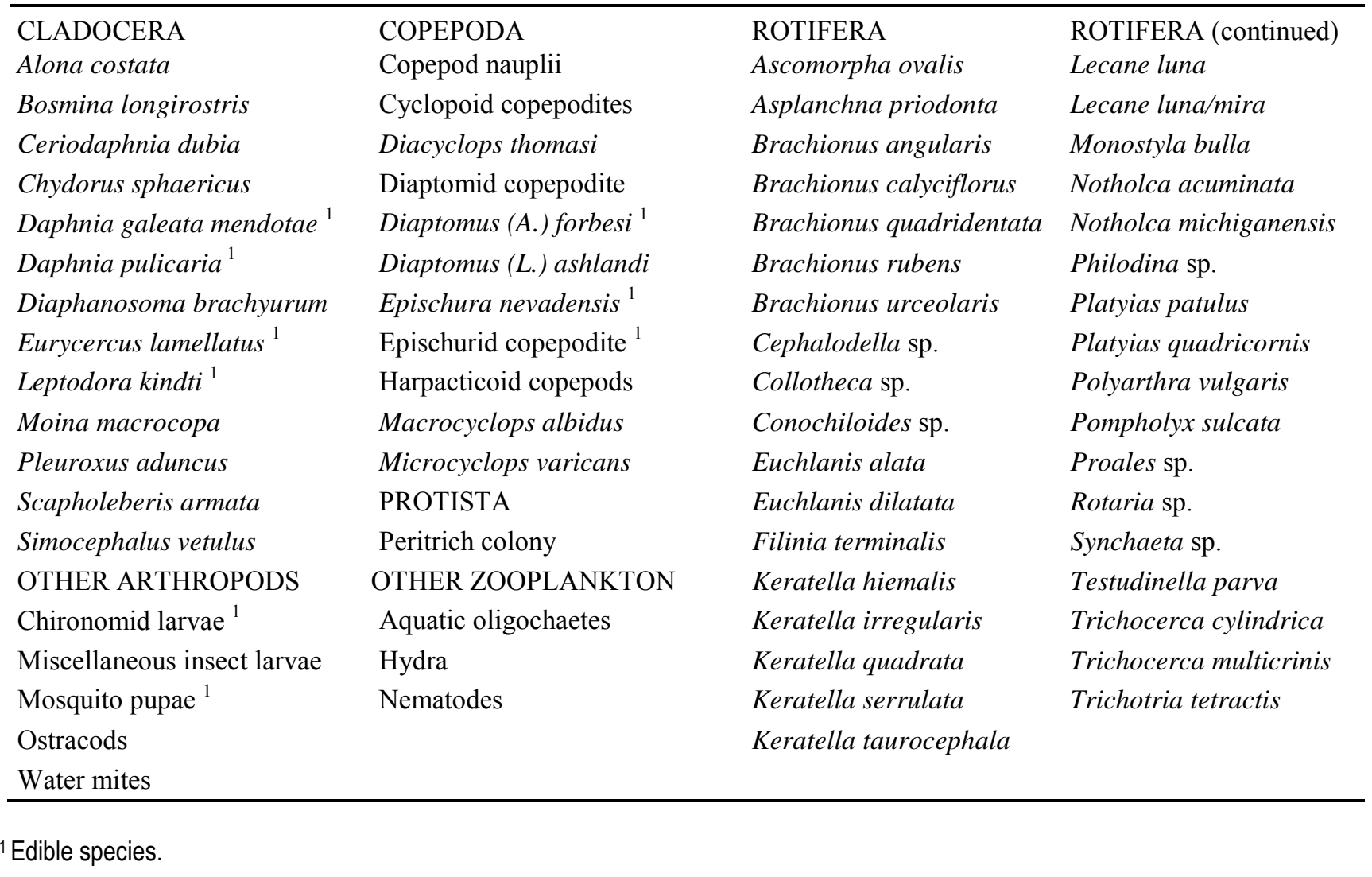

\section{Bacterial Abundance and Morphology}

Total bacterial populations ranged from 0.5 million to 92.2 million cells $/ \mathrm{mL}$, and generally increased into summer (fig. 2; Appendix D). Group 3 (cocci) was the most abundant bacteria morphotype, averaging 79 percent of total cell counts (at all sites through the season), with a range from 0 to 98.7 percent of total bacterial abundance. They were the smallest bacteria, with diameters of $0-0.2$ $\mu \mathrm{m}$. Their diameters were smaller than the filter pore sizes used for filtration: $0.7 \mu \mathrm{m}$ for organic carbon and $0.45 \mu \mathrm{m}$ for other constituents.

Although cocci were the most numerous bacteria, group 1 bacteria (large cells) made up most of the bacterial biovolume (figs. 2 and 3). The total bacterial biovolume maximum occurred between early July and mid-August, depending on the site. Biovolumes ranged from 0.04 to 8.6 million $\mu \mathrm{m}^{3} / \mathrm{mL}$.

Bacteria cells were observed attached to living algae and algal debris. Cells attached to algae were counted, and they comprised up to 19 percent of counted cells in samples. However, slide preparations had little particulate material, and to have a count greater than zero, a particle with attached cells had to appear in one of the counting fields. In some cases, such particles were observed outside the counting 
fields; these are noted in the data tables in the Appendix. Autofluorescent cells were also counted, and made up to 38 percent of counted cells per sample. No consistent relation between autofluorescence and cell morphology was observed.

\section{Acknowledgments}

This study was made possible with primary funding from the Bureau of Reclamation, with additional support from the U.S. Geological Survey. Gunter Schanzenbacher, April Tower, Matthew Kritzer, and James Ross (Reclamation) conducted weekly water quality field work. Jim Sweet (Aquatic Analysts) analyzed algae species samples. Allan Vogel (ZP's Taxonomic Services) analyzed the zooplankton samples. Elizabeth Jones (USGS) conducted bacteria counts. Mary Voytek and George Aiken of the USGS National Research Program provided guidance to bacteria and DOC work, respectively. Assistance from Jason Cameron (Reclamation), Stewart Rounds, Joseph Rinella, Dennis Lynch, and Matthew Johnston (USGS) were important to the success of the project. Jacqueline Olson (USGS) prepared the map. Insightful reviews by Stewart Rounds, Brent Topping, and Greg Fuhrer (USGS) improved the manuscript.

\section{References Cited}

Aiken, G.R., 1992, Chloride interference in the analysis of dissolved organic carbon by the wet oxidation method: Environmental Science and Technology, v. 26, p. 2435-2439.

American Public Health Association, 2005, Standard methods for the examination of water and wastewater, $21^{\text {st }}$ ed.: Washington D.C., 1368 p.

Berner, D., 1994, Key characteristics of north temperate Ceriodaphnia: Prepublished 6 p. of illustrations.

Brandlova, J., Brandl, Z., and Fernando, C.H., 1972, The Cladocera of Ontario with remarks on some species and distribution: Canadian Journal of Zoology, v. 50, p. 1373-1403.

Brooks, J.L., 1957, The systematics of North American Daphnia: Memoirs of the Connecticut Academy of Arts and Sciences, v. 13.

Brooks, J.L., 1969, Eutrophication and changes in the composition of the zooplankton, in Eutrophication-Causes, consequences, correctives, Proceedings of the International Symposium on Eutrophication: National Academy of Sciences Publication 1700, 661 p.

Bureau of Reclamation, 2005, Standard operating procedures for quality assurance, Revision 2005-01: $51 \mathrm{p}$.

Canale, R.P., DePalma, L.M., and Vogel, A.H., 1975, A food web model for Lake Michigan, Part 2 Model formulation and preliminary verification: Michigan Sea Grant Program Technical Report No. 43, accessed May 15, 2008, at http://dspace.udel.edu:8080/dspace/handle/19716/1451.

Canale, R.P., DePalma, L.M., and Vogel, A.H., 1976, A plankton-based food web model for Lake Michigan, in Canale, R.P., ed., Modeling biochemical processes in aquatic ecosystems: Ann Arbor, Michigan, Ann Arbor Science, p. 33-74.

Carlson, R.E., 1977, A trophic state index for lakes: Limnology and Oceanography, v. 22, no. 2, p. 361369.

Carpenter, S.R., and Kitchell, J.F., eds., 1993, The trophic cascade in lakes: Cambridge, Cambridge University Press, 399 p. 
Childress, C.T., Foreman, W.T., Connor, B.F., and Maloney, T.J., 1999, New reporting procedures based on long-term method detection levels and some considerations for interpretations of waterquality data provided by the U.S. Geological Survey National Water Quality Laboratory: U.S. Geological Survey Open-File Report 99-193, 19 p.

DeMont, R., and Hebert, P.D.N., 1994, A taxonomic revision of North American Bosminidae: Canadian Journal of Zoology, v. 72, p. 1808-1825.

Deevey, E.S., Jr., and Deevey, G.B., 1971, The American species of Eubosmina Seligo (Crustacea, Cladocera): Limnology and Oceanography, v. 16, p. 201-218.

Dumont, H.J., and Pensaert, J., 1983, A revision of the Scapholeberinae (Crustacea: Cladocera): Hydrobiologia, v. 100, p. 3-45.

Edmondson, W.T., ed., 1959, Fresh-water biology: Wiley, 1248 p.

Edmondson, W.T., and Winberg, G.G., eds., 1971, A manual on methods for the assessment of secondary productivity in fresh waters: Blackwell Scientific, IBP Handbook No. 17, 358 p.

Eilers, J.M., Loomis, D., St. Amand, A., Vogel, A., Jackson, L., Kann, J., Eilers, B., Truemper, H., Cornett, J., and Sweets, R., 2007, Biological effects of repeated fish introductions in a formerly fishless lake—Diamond Lake, Oregon, USA: Archiv für Hydrobiologie, v. 169, p. 265-277.

Fishman, M.J., ed., 1993, Methods of analysis by the U.S. Geological Survey National Water Quality Laboratory-Determination of inorganic and organic constituents in water and fluvial sediments: U.S. Geological Survey Open-File Report 93-125, 217 p.

Friedman, L.C., and Erdmann, D.E., 1982, Quality assurance practices for the chemical and biological analyses of water and fluvial sediment: U.S. Geological Survey Techniques of Water-Resources Investigations, book 5 , chap. A6, $181 \mathrm{p}$.

Hebert, P.D.N., 2001, The Daphnia of North America: University of Guelph, CyberNatural Software, CD.

Johnson, D.M., Petersen, R., Lycan, D., Sweet, J., Neuhause, M., and Schaedel, A., 1985, Atlas of Oregon lakes: Corvallis, Oregon State University Press, 318 p.

Jones, B.E., 1987, Quality control manual of the U.S. Geological Survey's National Water Quality Laboratory: U.S. Geological Survey Open-File Report 87-457, 17 p.

Kerfoot, W.C., ed., 1980, Evolution and ecology of zooplankton communities: Dartmouth College, University Press of New England, 794 p.

Korovchinsky, N.M., 1992, Sididae and Holopediidae (Crustacea: Daphniiformes), in Guides to the identification of the microinvertebrates of the continental waters of the world, v. 3: The Hague, SPD Academics, $82 \mathrm{p}$.

Kuwabara, J.S., Topping, B.R., Lynch, D.D., Carter, J.L., and Essaid, H.I., 2009, Benthic nutrient sources to hypereutrophic Upper Klamath Lake, Oregon, USA: Environmental Toxicology and Chemistry, v. 28, p. 516-524.

Lindenberg, M.K., Hoilman, G., and Wood, T.M., 2009, Water-quality conditions in Upper Klamath and Agency Lakes, Oregon, 2006: U.S. Geological Survey Scientific Investigations Report 20085201, 54 p., accessed May 15, 2009 at http://pubs.usgs.gov/sir/2008/5201/. 
Maloney, T.J., ed., 2005, Quality management system, U.S. Geological Survey National Water Quality Laboratory: U.S. Geological Survey Open-File Report 2005-1263, version 1.3, November 9, 2005, chapters and appendices [variously paged].

McNabb, C.D., 1960, Enumeration of freshwater phytoplankton concentrated on the membrane filter: Limnology and Oceanography, v. 5, p. 57-61.

Mrazik, S., 2007, Oregon water quality index summary water years 1997-2006: Oregon Department of Environmental Quality, DEQ07-LAB-007-TR, 13 p.

Mueller, D.K., Martin, J.D., and Lopes, T.J., 1997, Quality-control design for surface-water sampling in the national water-quality assessment program: U.S. Geological Survey Open-File Report 97-223, 17 p.

Murphy, T.P., Lean, D.R., and Nalewajko, 1976, Blue-green algae-Their excretion of iron-selective chelators enables them to dominate other algae: Science, v. 192, p. 900-902.

Noble, R.T., and Fuhrman, J.A., 1998, Use of Sybr Green I for rapid epifluorescence counts of marine viruses and bacteria: Aquatic Microbial Ecology, v. 14, p. 113-118.

Oregon Department of Environmental Quality, 2007, Oregon's 2004/2006 integrated report: accessed November 16, 2007, at http://www.deq.state.or.us/wq/assessment/rpt0406.htm.

PacifiCorp, 2002, Explanation of facilities and operational issues associated with PacifiCorp's Klamath hydroelectric project, FERC Project No. 2082 (Draft): Portland, Oregon, PacifiCorp, 44 pages.

Patterson, D.J., 1996, Free-living freshwater protozoa, a colour guide: Wiley, 223 p.

Patton, C.J., and Kryskalla, J.R., 2003, Methods of analysis by the U.S. Geological Survey National Water Quality Laboratory-Evaluation of alkaline persulfate digestion as an alternative to Kjeldahl digestion for determination of total and dissolved nitrogen and phosphorus in water: U.S. Geological Survey Water-Resources Investigations Report 03-4174, 33 p.

Pennak, R.W., 1989, Fresh-water invertebrates of the United States, $3^{\text {rd }}$ ed: Wiley, 648 p.

Pontin, R.M., 1978, A key to British freshwater planktonic Rotifera: Wallington, Surrey, England, Freshwater Biological Association, Science Publication No. 38, 178 p.

Pritt, J.W., and Raese, J.W., eds., 1995, Quality assurance/quality control manual—National Water Quality Laboratory: U.S. Geological Survey Open-File Report 95-443, 35 p.

Ruttner-Kolisko, A., 1974, Plankton rotifers, biology and taxonomy: Binnengewasser 26/1 Supplement, $146 \mathrm{p}$.

Schuster, P.F., ed., 2003, Water and sediment quality in the Yukon River basin, Alaska, during water year 2001: U.S. Geological Survey Open File Report 03-427.

Stemberger, R.S., 1979, A Guide to rotifers of the Laurentian Great Lakes: U.S. Environmental Protection Agency, EPA-600/4-79-021, 185 p..

Sweet, J.W., 1986, A survey and ecological analysis of Oregon and Idaho phytoplankton: Seattle, U.S. Environmental Protection Agency, 28 p.

Taylor, D. J., Ishikane, C.R., and Haney, R.A., 2002, The systematics of Holarctic bosminids and a revision that reconciles molecular and morphical evolution: Limnology and Oceanography, v. 47, p. 1486-1495. 
Thorp, J.H., and Covich, A.P., eds., 1991, Ecology and classification of North American freshwater invertebrates: Academic Press, 950 p.

U.S. Geological Survey, 2007, NWQL National Field Supply Service Quality Assurance Surveillance Plan (NFSS QASP): Denver, Colorado, U.S. Geological Survey National Water Quality Laboratory, $31 \mathrm{p}$.

Weinbauer, M.G., Beckmann, C., and Hofle, M.G., 1998, Utility of green fluorescent nucleic acid dyes and aluminum oxide membrane filters for rapid epifluorescence enumeration of soil and sediment bacteria: Applied and Environmental Microbiology, v. 64, no. 12, p. 5000-5003.

Weishaar, J.L., Aiken, G.R., Bergamaschi, B.A., Fram, M.S., Fujii, R., and Mopper, K., 2003, Evaluation of specific ultraviolet absorbance as an indicator of the chemical composition and reactivity of dissolved organic carbon: Environmental Science and Technology, v. 37, no. 20, p. 4702-4708.

Wetzel, R.G., 2001, Limnology: Lake and river ecosystems, 3rd edition: Academic Press, 1006 p.

Wilde, F.D., Radtke, D.B., Gibs, Jacob, and Iwatsubo, R.T., eds., 2004, Processing of water samples (version 2.1): U.S. Geological Survey Techniques of Water-Resources Investigations, book 9, chap. A5, accessed January 11, 2008, at http://pubs.water.usgs.gov/twri9A5/.

Zaret, T.M., 1980, Predation and freshwater communities: Yale University Press, 187 p.

Zimmerman, C.F., Keefe, C.W., and Bashe, J., 1997, Determination of carbon and nitrogen in sediments and particulates of estuarine/coastal waters using elemental analysis-Method 440.0: U.S. Environmental Protection Agency, accessed May 8, 2008 at http://www.epa.gov/nerlcwww/m440_0.pdf

\section{Appendixes}

Appendix A. Quality Control Data

Appendix B. Water Quality Data

Appendix C. Phytoplankton and Zooplankton Data

Phytoplankton raw data

Zooplankton raw data

Appendix D. Bacteria Data 